Revista Eletrônica de Direito Processual - REDP.

Rio de Janeiro. Ano 11. Volume 18. Número 2. Maio a Agosto de 2017

Periódico Quadrimestral da Pós-Graduação Stricto Sensu em Direito Processual da UERJ

Patrono: José Carlos Barbosa Moreira. ISSN 1982-7636. pp. 393-436

www.redp.uerj.br

\title{
PRECEDENTES VS. PONDERAÇÃO: CONTRADIÇÃO INTERNA DO CÓDIGO DE PROCESSO CIVIL VIGENTE ${ }^{1}$
}

\section{PRECEDENTS VS. BALANCING: INNER CONTRADICTION OF CURRENT PROCESS CIVIL BRAZILIAN STATUTE}

Manoel Pedro Ribas de Lima Advogado. Mestre em Direito Constitucional pela UniBrasil. Ponta Grossa/RS. manoel@ ribasdelima.com.br

RESUMO: Investiga-se a contradição entre paradigmas do vigente Código de Processo Civil. De um lado está o efeito de vertical dos precedentes, cujo pressuposto é a identidade entre caso para a replicação da decisão e objetivo é a segurança jurídica. De outro lado está a ponderação, cujo pressuposto é a singularidade da decisão para o caso concreto e assume a contingência como ônus inesgotável. Para tanto, partiu-se da análise da norma jurídicopositiva e da história institucional de procedimentos anteriores que se assemelham aos postulados investigados para, então, adentrar na recente doutrina sobre os temas. Identificouse a contradição mencionada, seus efeitos próximos e as possibilidades iniciais de soluções. Além do exame bibliográfico e de leading cases, valeu-se do método crítico. Constatou-se o divórcio entre do discurso normativo, do qual os precedentes estão contidos, e o ato de decisão jurisdicional do litígio atual.

PALAVRAS-CHAVE: Processo civil, precedentes, efeito vertical, ponderação, norma e decisão.

ABSTRACT: It investigates the contradiction between paradigms of the current Process Civil Statute. On the one hand is the vertical effect of precedents, whose assumption is the identity between case for the replication of the decision and objective is legal certainty. On

\footnotetext{
${ }^{1}$ Artigo recebido em 05/05/2017 e aprovado em 28/06/2018.
} 
Revista Eletrônica de Direito Processual - REDP.

Rio de Janeiro. Ano 11. Volume 18. Número 2. Maio a Agosto de 2017

Periódico Quadrimestral da Pós-Graduação Stricto Sensu em Direito Processual da UERJ

Patrono: José Carlos Barbosa Moreira. ISSN 1982-7636. pp. 393-436

www.redp.uerj.br

the other hand is the balancing, whose assumption is the uniqueness of the decision for the case and takes the contingency as an endless burden. To do so, it was based on the analysis of the legal-positive norm and the institutional history of previous procedures that resemble the investigated postulates to then enter into the recent doctrine on the themes. The mentioned contradiction was identified, as well as its near effects and close the initial possibilities of solutions. In addition to the literature review and leading cases, the critical method was used. It was found the divorce between the normative discourse, of which the foregoing are contained, and the act of judicial decision of the current dispute.

KEYWORDS: Process, precedents, vertical effect, balancing, norm e decision.

SUMÁRIO: Definição do debate: a duplicidade paradigmática do novo CPC; 2. Concepção jurídico-positiva dos precedentes e enquadramentos típicos; 3 . Ponderação e o caso concreto como fator efetivo da decisão; 4. O resultado da convivência entre os efeitos dos precedentes e a ponderação; 5. Conclusão; Referências Bibliográficas.

\section{DEFINIÇÃO DO DEBATE: A DUPLICIDADE PARADIGMÁTICA DO NOVO CPC}

Como produto da assimilação das diretrizes da Constituição da República de 1988, sem dúvidas sob a matiz neoconstitucionalista, o novo Código de Processo Civil (Lei 13.105 de 16 de março de 2015) positiva como basilares dois postulados: os efeitos verticais dos precedentes (CPC, art. 927) e a exigência de ponderação das decisões (CPC, art. $\left.8^{\circ}\right)$.

Os efeitos verticais dos precedentes possuem um papel de aperfeiçoamento. Os precedentes suprimiriam lacunas legais e zonas cinzentas, dirigindo hermeneuticamente a construção da norma. Além disto, os precedentes forneceriam uma previsibilidade à resolução de casos particulares, o que as normas legais, marcadas por sua abstração, não poderiam proporcionar. Haveria, então, tanto uma possibilidade concreta de uma totalidade ao ordenamento quanto segurança aos negócios e atos jurídicos.

O exame de ponderação (Abwägung ou Balancing), também chamado de princípio de proporcionalidade (Verhältnismäßigkeitsprinzip), circunscreve o discurso normativo. Por 
Revista Eletrônica de Direito Processual - REDP.

Rio de Janeiro. Ano 11. Volume 18. Número 2. Maio a Agosto de 2017

Periódico Quadrimestral da Pós-Graduação Stricto Sensu em Direito Processual da UERJ

Patrono: José Carlos Barbosa Moreira. ISSN 1982-7636. pp. 393-436

www.redp.uerj.br

mais específicas em seu conteúdo, as normas não são capazes de atender o ineditismo e a singularidade de cada caso concreto. As normas sempre existem logicamente a priori ao litígio, precárias em seu âmbito de incidência. As particularidades do litígio concreto são elevadas à condição sine qua non da decisão, reclamando a justiça nos horizontes de cada caso $\left(\mathrm{CPC}\right.$, art. $\left.6^{\circ}\right)$. O julgamento do caso concreto não se trata de mera aplicação da norma, senão o produto da ponderação das normas vigentes no ordenamento jurídico ao caso concreto.

Embora se possa dizer que ambas as exigências sejam inspiradas em tradições jurídicas distintas, efeitos verticais dos precedentes e o exame de ponderação estão calcados na ideia da atuação integralizadora do julgador. Integração é a pretensão de compreensão, material e espiritual, necessária diante da incompletude do fenômeno normativo e/ou da finitude do observador. A norma jurídico-positiva, enunciada na lei, seria sempre insuficiente. Inevitavelmente, critérios transcenderão às colocações legais ${ }^{2}$. Haveria um fit interpretativo ${ }^{3}$ construído pelo intérprete que, apesar do bem da vida pressuposto na vigência da norma já positivada, exige uma conformação, contando com a atuação positiva do julgador. O papel esperado para ele é o encontro do todo, tomando cada evento como parte daquele, ou, em outras palavras, a construção de uma racionalidade própria para o Direito.

Estando corretas as concepções de efeitos verticais dos precedentes e de ponderação, tal qual se aprofundará neste trabalho, percebe-se uma contradição. Há duas linhas paralelas de forças de motivação para a decisão. Cada uma delas busca apresentar respostas através de fontes distintas. Os efeitos verticais dirigem-se ao encerramento do ordenamento; o exame de ponderação está condicionado à abertura da normatividade. Ordenamento vs. caso concreto. Não se resume a colocar de um lado a causa de pedir e de outro o stare decisis.

Metodologicamente, a integralização dos precedentes atua subsidiariamente aos enunciados legais, integrando, perante o julgamento do caso concreto, o discurso normativo. A partir disto pode-se falar de um arcabouço positivo de respostas. De outro lado, a

\footnotetext{
${ }^{2}$ FERRAZ JUNIOR, Tércio Sampaio. A ciência do direito. 2. ed. São Paulo: Atlas, 1986, p. 85.

${ }^{3} \mathrm{Um}$ fazer, um ato positivo, pois in claris non fit interpretatio.
} 
Revista Eletrônica de Direito Processual - REDP.

Rio de Janeiro. Ano 11. Volume 18. Número 2. Maio a Agosto de 2017

Periódico Quadrimestral da Pós-Graduação Stricto Sensu em Direito Processual da UERJ

Patrono: José Carlos Barbosa Moreira. ISSN 1982-7636. pp. 393-436

www.redp.uerj.br

ponderação extrai do problema sua resposta. Pressupõe-se, então, uma incapacidade do discurso normativo (sendo o stare decisis parte deste). Pragmaticamente falando, sob a ótica da ponderação, os efeitos verticais dos precedentes representam respostas prontas, distorcendo todo litígio em petitio principii às avessas (a própria litigiosidade seria uma ilegalidade, não mais um problema a ser resolvido); ao juízo restaria apenas selecionar dentre normas legais e precedentes o que melhor se adequa ao caso. Em sentido contrário, para os efeitos verticais dos precedentes, a ponderação exige um ceticismo, negando toda e qualquer reposta pronta (isto é, pondo em xeque toda e qualquer norma e, ainda, precedente); o que resultaria na ab-rogação da segurança jurídica (jurisprudência lotérica ${ }^{4}$ ) e uma indagação da aplicação normativa.

O trabalho visa apresentar, ainda não resolver, a contradição entre efeitos verticais dos precedentes e exame de ponderação, bem como a insuficiência do Código em atender esta questão.

\section{CONCEPÇÃO JURÍDICO-POSITIVA DOS PRECEDENTES E ENQUADRAMENTOS TÍPICOS}

Não há concepção patente sobre precedentes na experiência jurídica brasileira. Embora presente no cotidiano judiciário desde as antigas coletâneas até a atual acessibilidade eletrônica, o papel ativo dos precedentes confirma-se institucionalmente apenas com a determinação de seus efeitos pelo Código de Processo Civil vigente.

Fala-se de precedentes não em sua formação, mas de seu ofício na decisão vindoura. Pressupõe-se existir um arcabouço de precedentes a serem levados em conta no julgamento do litígio atual. Por isso a delimitação jurídico-positiva dos efeitos passa a ser o primeiro fator de análise.

Quando se fala de eficácia volta-se às possibilidades abertas legal e institucionalmente à adesão, e não a adesão ela mesma, dos juízes e tribunais de justiça aos

\footnotetext{
${ }^{4}$ NOGUEIRA, Gustavo Santana. Jurisprudência vinculante no direito norte-americano e no direito brasileiro; in WAMBIER, Teresa Arruda Alvim. (Coord.). Revista de Processo. Ano 33, nº 161. São Paulo: Revista dos Tribunais, jun/2008, p. 112.
} 
Revista Eletrônica de Direito Processual - REDP.

Rio de Janeiro. Ano 11. Volume 18. Número 2. Maio a Agosto de 2017

Periódico Quadrimestral da Pós-Graduação Stricto Sensu em Direito Processual da UERJ

Patrono: José Carlos Barbosa Moreira. ISSN 1982-7636. pp. 393-436

www.redp.uerj.br

precedentes $^{5}$. Esta análise é, antes, negativa e, depois, construtiva. Observa-se como os precedentes não serão acolhidos para, então, ver como eles podem o ser.

Uma análise legal do instituto não abarcará todo o fenômeno hoje testemunhado. $\mathrm{O}$ Código de Processo Civil vigente não foi o primeiro passo para essa eficácia dos precedentes dos tribunais superiores, senão consubstanciou a força institucional destes tribunais. Para que não se caia no erro de conceitos prontos, impostos ao cotidiano antes de constatados, propõe-se, após a análise legal, uma investigação histórico-institucional da relação dos tribunais superiores com as instâncias ordinárias, possibilitando aos leitores se colocarem no lugar dos atuais atores jurídicos e perceberem como estes enxergam os precedentes.

\subsection{Efeitos estabelecidos aos precedentes pelo Código de Processo Civil vigente}

Sempre houve na tradição continental adotada pelos brasileiros a percepção da decisão jurídica passada. Seu papel era apenas um: estabilização da relação jurídica singular. A rigidez atribuída pela coisa julgada material restringia o questionamento da decisão apenas às partes do processo. Sem repercussão para terceiros, a crítica permanecia aberta: admitiase posições novas a despeito de decisões pretéritas. Os juízes contavam com independência para julgar os litígios (Lei Complementar $n^{\circ} 35 / 1979$, art. 40). Fossem qual fossem as posições dos tribunais superiores, fundamentação normativa por juízo competente bastava para a validade da decisão (Constituição da República, art. 93, IX c/c art. 5º II e Dec. Lei 4.657/42, art. $4^{\circ}$ ). Assim permanece, ao menos, nas matérias que ainda não superaram o duplo grau de jurisdição (CPC, art. 503 c/c 506). As coisas mudaram quando, indiferentemente à conexão ou à prejudicial de mérito, definiu-se o modo como ecoam as decisões proferidas pelos tribunais superiores umas sobre as outras tanto quanto sobre as decisões dos juízes monocráticos e tribunais de justiças.

Segundo o Código vigente, em seu art. 927, III, toda a atividade jurisdicional deve observar os acórdãos proferidos pelos tribunais superiores em julgamento de recursos

\footnotetext{
${ }^{5}$ FERRAZ JUNIOR, Tercio Sampaio. Introdução ao estudo do direito: técnica, decisão, dominação. 4. ed. São Paulo: Atlas, 2003, p. 193.
} 
Revista Eletrônica de Direito Processual - REDP.

Rio de Janeiro. Ano 11. Volume 18. Número 2. Maio a Agosto de 2017

Periódico Quadrimestral da Pós-Graduação Stricto Sensu em Direito Processual da UERJ

Patrono: José Carlos Barbosa Moreira. ISSN 1982-7636. pp. 393-436

www.redp.uerj.br

repetitivos. A expressão observar, ao menos textualmente, não traz qualquer conotação específica. E não há, nesse enunciado, nenhum termo que remeta à vinculação ou não do julgador aos precedentes.

Dentro do mesmo diploma encontram-se, num esforço sistêmico interno, as exigências de que (i) nenhuma ação deverá prosperar se contrariar súmulas e acórdãos repetitivos dos tribunais superiores (CPC, art. 332, II); de que (ii) serão prestadas tutelas de evidência em hipóteses aceitas em súmulas e acórdãos repetitivos (CPC, art. 311, II); e de que (iii) recursos não serão conhecidos quando sustentam teses opostas à súmulas e acórdãos repetitivos (CPC, art. 932, IV).

Daquelas três exigências citadas (improcedência liminar do pedido, hipótese de tutela de evidência e negativa de provimento de recurso) constata-se da eficácia dos precedentes a decomposição de duas extensões. Num aspecto formal está o alcance dos precedentes aos fundamentos da decisão jurisdicional, mas sem determiná-la. Ao reduzir a este aspecto, o juiz deveria sempre mencionar os precedentes, mas não estaria obrigado a segui-los (não sendo especificamente um critério integrativo, mas um lastro de segurança de seus argumentos). Isso confirmar-se-ia no inc. $\mathrm{V}$ do $§ 1^{\circ}$ do art. 489 do Código de Processo Civil, onde se enuncia que o juiz, ao julgar o litígio, não pode se limitar a trazer os precedentes já existentes (presumindo uma necessária remissão legal para a fundamentação). Num aspecto material pode-se dizer com segurança que, salvo na hipótese de coisa julgada do caso debatido, os precedentes vinculam juízes e tribunais de justiça diretamente e de modo ex nunc, sob pena de cassação da decisão por reclamação $\left(\mathrm{CPC}\right.$, art. $\left.985, \S 1^{\circ}\right)$. A resolução do litígio deveria corresponder imediatamente os termos fixados pelos seus precedentes. Os precedentes revelam-se, no mínimo, critério integrativo, aguçando o conteúdo da norma aplicada. O julgador não pode deixar de acompanhá-los, dizendo alguns que os precedentes tornam-se fontes primárias normativas ${ }^{6}$. Surge uma verticalidade

\footnotetext{
${ }^{6}$ MITIDIERO, Daniel. Precedentes: da persuasão à vinculação. 2 ed. São Paulo: Revista dos Tribunais, 2017, p. $85-86$.
} 
Revista Eletrônica de Direito Processual - REDP.

Rio de Janeiro. Ano 11. Volume 18. Número 2. Maio a Agosto de 2017

Periódico Quadrimestral da Pós-Graduação Stricto Sensu em Direito Processual da UERJ

Patrono: José Carlos Barbosa Moreira. ISSN 1982-7636. pp. 393-436

www.redp.uerj.br

evidente entre, de um lado, os tribunais superiores e, de outro, os juízes e os tribunais de justiças ${ }^{7}$.

A coexistência de ambos os aspectos, contudo, não é harmônica. Na sua manifestação material, os precedentes sobrepõem-se à manifestação formal, enquanto a formal não elimina a material - não seria a ausência de vinculação material que impediria o julgador de reprisar o precedente em sua decisão. A solução para a determinação da extensão de cada aspecto é dada pelo Código na similaridade do precedente ao litígio julgado. O inc. VI do $\S 1^{\circ}$ do art. 489 do Código é expresso na necessidade de desconstrução manifesta do precedente para afastá-lo como critério final da decisão - somente no insuficiente aspecto material dar-se-ia espaço ao aspecto formal?

A constatação da verticalidade material dos precedentes responde apenas parte da questão. Esse novo fator, a exigência de desconstrução, não é tão óbvio e demanda atenção especial. Com a análise estrita da eficácia dos precedentes ainda não estará claro como os precedentes são percebidos pelos juízes e tribunais de justiça.

2.2. Definição do aspecto material da eficácia pela tese jurídica

Se o aspecto formal da eficácia dos precedentes, aquela que deixa ao juiz a competência criativa de encontrar uma resolução ao litígio, for meramente subsidiário, o segundo fator efetivo para a determinação do papel dos precedentes será a dimensão do aspecto material. Ao perguntar como os precedentes são percebidos no julgamento do litígio atual, debruça-se sobre as condicionalidades da eficácia. Em jogo está a estrutura normativa do precedente, denominada legalmente de tese jurídica, modulando o "como" o seu conteúdo será apreendido dentro da decisão a ser proferida.

Não há conceituação legal de tese jurídica, senão propriedades de sua manifestação. Chave para a questão são os dois incisos do art. 985 combinados com o $§ 2^{\circ}$ do art. 926 do

\footnotetext{
${ }^{7} \mathrm{O}$ efeito vertical é distinguido por Frederick Schauer em relação ao efeito horizontal por ser este aquele existente entre membros da mesma instituição, afastando uma hierarquia entre diferentes instituições. SCHAUER, Frederick. Thinking like a lawyer, sem página, apud PUGLIESE, William. Precedentes e a civil law brasileira: interpretação e aplicação do novo código de processo civil. São Paulo: Revista dos tribunais, 2016, p. 84, nota 19.
} 
Revista Eletrônica de Direito Processual - REDP.

Rio de Janeiro. Ano 11. Volume 18. Número 2. Maio a Agosto de 2017

Periódico Quadrimestral da Pós-Graduação Stricto Sensu em Direito Processual da UERJ

Patrono: José Carlos Barbosa Moreira. ISSN 1982-7636. pp. 393-436

www.redp.uerj.br

Código vigente. Os primeiros ditam as fronteiras da tese jurídica por meio da equivalência das questões de Direito entre precedente e litígio atual; equivalência esta que recebe eficácia materialmente vertical como descrita acima. O segundo dispositivo atribui aos tribunais a aplicação de sua jurisprudência na medida das circunstâncias fáticas do precedente inaugural.

Atenta-se, antes, para o fato de que dos precedentes se retira a capacidade de afetar a coisa julgada já constituída, seja esgotando sua exigibilidade (CPC, art. 525, §12º, seja motivando sua rescisão (CPC, art. 525, §15 c/c art. 966, V), quando dissociados das decisões de controle de constitucionalidade abstrato. Por ora pode-se dizer que se presume dos precedentes o julgamento de casos particulares já que as decisões de controle de constitucionalidade abstrato acontecem em tese (CPC, art. 988, III, com redação dada pela Lei 13.256/2016).

Um é por não ser o outro; e se o é, são as mesmas coisas. A alteridade responde

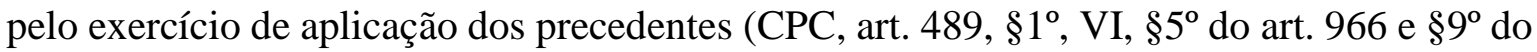
art. 1.037). E a exigência de distinção considera similaridades. A soma da equivalência jurídica com a equivalência fática impõe o pressuposto da existência de litígios idênticos passíveis a uma mesma decisão. $\mathrm{E}$ aqui surge a primeira hipótese deste trabalho. $\mathrm{O}$ ordenamento jurídico brasileiro não admite cogitar teses amplas aos precedentes, suscetíveis à analogia. A experiência do common law não será recepcionada. Disto desprende-se que os precedentes brasileiros não atuam como meios que problematizam e aprofundam o debate, mas sim como enquadramentos típicos a serem postos.

Lá na common law, mesmo que o caso verse sobre uma espécie de litígio, seu entendimento o transcende de tal modo que pode ser aplicado em litígios distintos. Por exemplo: o caso MacPherson v. Buick Motor Co., 217 N.Y. 382, decidido pela Corte de Apelação de Nova York em 1916, debatia a pretensão ou não do comprador à perdas e danos por vícios redibitórios na coisa comprado (especificamente, um automóvel com rodas defeituosas). Pela procedência do pedido do comprador sustentou-se a ideia de que caberia ao vendedor garantir a oferta, dispensando o comprador o cuidado de examinar a coisa comprada. Esse entendimento, em sua vigência, não se confinou, a partir de então, à compra e venda de automóveis, mas também se tornou eficaz a todo e qualquer negócio jurídico sob 
Revista Eletrônica de Direito Processual - REDP.

Rio de Janeiro. Ano 11. Volume 18. Número 2. Maio a Agosto de 2017

Periódico Quadrimestral da Pós-Graduação Stricto Sensu em Direito Processual da UERJ

Patrono: José Carlos Barbosa Moreira. ISSN 1982-7636. pp. 393-436

www.redp.uerj.br

aquele ordenamento que envolva tradição da coisa (locação, comodato, algumas garantias, etc.). A chave não está na tipificação do caso, mas em um elemento comum e transcendente a eles. Os precedentes antes inspirariam a decisão, não havendo meras repetições (não se pressupõe casos idênticos ${ }^{8}$ ). Se pondera sobre o precedente ${ }^{9}$. O papel dos precedentes na common law não parece ser apenas o de determinar a decisão, mas antes de assegurar legitimidade, sendo um modo de fundamentação da decisão do litígio atual ${ }^{10}$. E falar de distinção aqui remete antes à relação entre argumentos, não entre casos. Na compra de bens móveis, se a coisa é destruída antes da tradição, o ônus é do vendedor (Hinggs vs. Murray, 73 N.Y. 252, 254), mas se a compra é de bens imóveis, o ônus é comprador (Paine vs. Meller, 6 Ves. 349,352) - mesmo negócio jurídico, diferentes argumentos. Tudo isso porque o método aí vigente é o indutivo (do caso para um motivo subjacente da decisão) ${ }^{11}$, não dedutivo, o que faz da decisão do litígio atual muito mais circunstancial do que repetição do precedente que lhe deu sustento. Resta aberta a possibilidade de casos semelhantes terem decisões diferentes, como casos análogos suportarem a mesma decisão. Tudo isso torna problemática, demandando sempre certo esforço investigativo, a aplicação do precedente bem com a escolha do melhor precedente ao litígio atual sob os olhos da common law ${ }^{12}$.

Esta experiência é incomunicável para a realidade brasileira. Ensaia-se a seguinte hipótese: a aplicação do Habeas Corpus no 124.306 num caso de eutanásia. A decisão tomada pela Primeira Turma do Supremo Tribunal Federal no Habeas Corpus citado afastou a prisão preventiva dos pacientes pela descriminalização do aborto ocorrido até três meses contados

\footnotetext{
${ }^{8}$ WAMBIER, Teresa Arruda Alvim. Estabilidade e adaptabilidade como objetivos do direito: civil law e common law; in Revista de Processo. Vol. 172. Jun/2009, p. 121 (p.4 e 15).

${ }^{9}$ LEVI, Edward H. An introduction to Legal Reasoning, 1949, sem página, e FRANK, Jerome. Courts on Trail. 1949, sem página, apud ROSS, Alf. Direito e Justiça. Trad. Edson Bini. Bauru: Edipro, 2003, p. 113, nota 11, e p. 114.

${ }^{10}$ PUGLIESE, William. Precedentes e a civil law brasileira: interpretação e aplicação do novo código de processo civil. São Paulo: Revista dos tribunais, 2016, p. 42-43.

${ }^{11}$ CARDOZO, Benjamin N. A natureza do processo judicial: palestras proferidas na Universidade de Yale. Trad. Silvana Vieira. São Paulo: Martins Fontes, 2004, p. 12. Também fonte dos precedentes citados, ver p. 118-119. Dworkin defende, a partir da sua teoria, que a força gravitacional dos precedentes repercute como princípios e que só podem ser sustentados enquanto suportados pelos direitos já positivados. Ver em DWORKIN, Ronald. Taking Rights Seriously. Cambridge, Harvard, 1978, p. 115.

12 ABBOUD, Georges. Súmula vinculante versus precedentes: notas para evitar alguns enganos; in: WAMBIER, Teresa Arruda Alvim (Coord.). Revista de Processo. Nov/2008. Ano 33. n. 165. São Paulo: Revista dos tribunais, 2008, p. 222.
} 
Revista Eletrônica de Direito Processual - REDP.

Rio de Janeiro. Ano 11. Volume 18. Número 2. Maio a Agosto de 2017

Periódico Quadrimestral da Pós-Graduação Stricto Sensu em Direito Processual da UERJ

Patrono: José Carlos Barbosa Moreira. ISSN 1982-7636. pp. 393-436

www.redp.uerj.br

da gestação. Da legalidade do aborto com o consentimento da gestante pode-se extrair que toda vida insubsistente poderia ser esgotada quando autorizada por aquele de quem aquela vida depende ${ }^{13}$. A partir disso, em nome da autonomia do cuidador, que suporta o ônus de manter um moribundo, este moribundo poderia ter sua vida esgotada. $\mathrm{O}$ aborto não tem $\mathrm{o}$ mesmo espectro que o da eutanásia neste argumento? A diferenciação circunstancial do litígio não implica na inibição da tese, pois o raciocínio é o mesmo, os casos são análogos e o resultado é equivalente. Mas o jurista pátrio se oporá, pois entenderá que o precedente proferido no caso de aborto cabe apenas para situações de aborto.

O que inibe uma estrutura amplificada aos precedentes e um método indutivo no seu uso na realidade brasileira é a reunião de fatores. A mais reveladora é a segunda condição de aplicação dos precedentes antes mencionada: a identidade de circunstância fática. A alteridade acontece tanto entre teses quanto entre casos. Espera-se do precedente certa substancialização da norma legal ${ }^{14}$. Do precedente o jurista brasileiro espera algo específico. Com efeito, se por mandados de otimização se manifestassem os precedentes, seria impossível exceções aos sobrestamentos por recursos repetitivos (CPC, art. 1.035, §6 $6^{\circ}$. Além disto, os tribunais superiores brasileiros contam com a tradição continental e com o peso de inúmeros processos ${ }^{15}$. De um lado está um legado positivista, que exige tanto de regras quanto de princípios uma aplicação analítica (como veremos adiante); de outro está a reclamação de eficiência do judiciário pelo engrandecimento da ideia de tutela de direitos. Com o desenvolvimento jurisprudencial pretende-se, então, a maior objetividade do conteúdo normativo ${ }^{16}$.

\footnotetext{
${ }^{13}$ Esse caso difere em muito da ADPF 54, que autoriza o aborto no caso de gestação de feto anencefálico. Em primeiro lugar, a ADPF trabalha em tese, não se circunscrevendo à situação específica. Em segundo, neste caso não há só insustentabilidade atual da vida do feto, mas a certeza de nascimento desprovido de qualquer consciência e da certeza da morte imediata. Seria mais cabível, na sua radicalização, a comparação com a morte cerebral, com o desligamento dos aparelhos que mantem o corpo vivo.

${ }^{14}$ PUGLIESE, William. Precedentes e a civil law brasileira: interpretação e aplicação do novo código de processo civil. São Paulo: Revista dos tribunais, 2016, p. 91 e 96.

${ }^{15}$ BARROSO, Luís Roberto. MELLO, Patrícia Perrone Campos. Trabalhando com uma nova lógica: a ascensão dos precedentes no direito brasileiro, p. 3-4. Out/16. Disponível em: http://www.conjur.com.br/2016out-28/artigo-barroso-explica-precedentes-cpc-muda-direito. Acesso em 31/01/2017.

${ }^{16}$ STRECK, Lenio Luiz. ABBOUD, Georges. O que é isto - o sistema (sic) de precedentes no CPC? in: Consultor jurídico. 18 de agosto de 2016. Disponível em: http://www.conjur.com.br/2016-ago-18/ensoincomum-isto-sistma-sic-precedentes-cpc. Acesso em 19.08.2016.
} 
Revista Eletrônica de Direito Processual - REDP.

Rio de Janeiro. Ano 11. Volume 18. Número 2. Maio a Agosto de 2017

Periódico Quadrimestral da Pós-Graduação Stricto Sensu em Direito Processual da UERJ

Patrono: José Carlos Barbosa Moreira. ISSN 1982-7636. pp. 393-436

www.redp.uerj.br

A tipificação dos casos afastará gradativamente o uso da verossimilhança, afunilando o método analítico para o mais apurado juízo determinante. Finda-se no litígio atual o debate tanto sobre as zonas cinzentas das normas legais quanto sobre as antinomias. O enquadramento da tese jurídica especificará a solução de tal modo que rotule o litígio a ser julgado. A tese jurídica, como trazida pelo Código de Processo Civil vigente, equivalese a noção contrafática de norma: projeta-se dela um conteúdo específico, do qual se busca o fato correspondente.

Em 2015 o Superior Tribunal de Justiça definiu a responsabilidade pela contribuição condominial incidente durante vigência de compromisso de compra e venda de unidade. Apesar de ser a contribuição condominial uma obrigação propter rem (Lei 4.591/1964, art. 12, e C. Civil, art. 1.336, I), o Recurso Especial n 1345331/RS, decidido na condição de recurso repetitivo, definiu que o promitente vendedor (ainda proprietário) deixa de ser responsável pela contribuição, recaindo este encargo sobre o promitente comprador (portando este apenas um direito in contrahendo), quando somadas a imissão da posse pelo promitente comprador e a ciência do condomínio sobre o negócio. Poderíamos concluir que há uma regra geral (a obrigação propter rem) e uma exceção particular (a substituição do proprietário pelo promitente comprador). Mas não é isto que acontece, como evidencia uma terceira situação. Quanto a unidade alienada permanece vazia durante o compromisso, compromisso cujo contrato se omite sobre a imissão da posse, tanto não é autorizado presumir que do compromisso decorra imediatamente a imissão da posse ao promitente comprador quanto não é possível presumir que a posse continua com o titular registral. $\mathrm{O}$ conhecimento do negócio pelo condomínio é indiferente. Ora a posse não exige o exercício do uso imediato da coisa, podendo ser ela presumida a partir tanto do domínio quanto do negócio jurídico. Poder-se-ia dizer que, nesta incerteza sobre a posse, vigeria a regra geral: seria do proprietário exigido a contribuição, tendo este, eventualmente, direito de regresso contra o promitente comprador. Todavia o mesmo Superior Tribunal de Justiça definiu uma nova tese para esse terceiro caso. Nos termos do Recurso Especial n ${ }^{\circ}$ 1442840/PR, na impossibilidade de demonstração pelo condomínio da imissão da posse do promitente comprador, caberá tanto ao promitente vendedor quanto ao promitente comprador, concorrentemente, a responsabilidade pelos valores inadimplidos. Este exemplo manifesta a 
Revista Eletrônica de Direito Processual - REDP.

Rio de Janeiro. Ano 11. Volume 18. Número 2. Maio a Agosto de 2017

Periódico Quadrimestral da Pós-Graduação Stricto Sensu em Direito Processual da UERJ

Patrono: José Carlos Barbosa Moreira. ISSN 1982-7636. pp. 393-436

www.redp.uerj.br

exigência do julgador brasileiro de agir sempre através de categorias estritas. A dicotomia 'regra geral / exceção' perde sua preponderância e tampouco se pode falar de um princípio norteador, seja pelos precedentes ou pelas normas legais. Haverá teses particulares para casos particulares. No nosso exemplo três enquadramentos típicos: (i) a obrigação propter rem para o caso do proprietário ordinário, (ii) a responsabilidade do promitente comprador no caso de seu exercício manifesto da posse e (iii) responsabilidade concorrente entre promitente vendedor e promitente comprador quando conhecido o negócio mas ignorada ou incerta a transmissão da posse.

A definição da dimensão do âmbito material aos precedentes (tese jurídica) encontrada pelo Código de Processo Civil é a manutenção da dicotomia quaestio juris e quaestio facti ${ }^{17}$. No seu art. 489, $\S 1^{\circ}, \mathrm{V}$ e VI, o Código traz a exigência do exame de adequação e alteridade entre o eventual precedente aplicado e o caso concreto. $O$ precedente seria apenas uma cristalização da norma, colocando as claras o comando legal. Isso confunde conteúdo normativo, também chamado de suporte fático, com a própria norma. Norma resumir-se-ia a exigência de uma conduta, seja ela qual for. Os precedentes afastariam qualquer dúvida sobre os limites do conteúdo. Portanto, ao julgador restaria, tão-somente, a identificação da verossimilhança entre o conteúdo da norma e o caso concreto (inc. V) ou sua distinção (IV). A motivação a ser prestada na fundamentação sempre já seria prévia. A alteridade para circunscrição da tese jurídica desqualifica a analogia e o uso de razões maiores. Afasta-se toda necessidade do exame de ponderação. Reclamar-se-á a identidade de premissas de tal modo que, pelos precedentes, a lógica jurídica equivalha à lógica pura. Soluções Xs para casos Xs, soluções Ys para casos Ys. Tudo ou nada. O silogismo nunca será mais adequado do que agora: tratar-se-á os litígios como recorrências dos seus precedentes.

\footnotetext{
${ }^{17}$ Dicotomia já pretendida pelos redatores do texto do código vigente. WAMBIER, Teresa Arruda Alvim. Estabilidade e adaptabilidade como objetivos do direito: civil law e common law; in Revista de Processo. Vol. 172. Jun/2009, p. 121 (p. 6).
} 
Revista Eletrônica de Direito Processual - REDP.

Rio de Janeiro. Ano 11. Volume 18. Número 2. Maio a Agosto de 2017

Periódico Quadrimestral da Pós-Graduação Stricto Sensu em Direito Processual da UERJ

Patrono: José Carlos Barbosa Moreira. ISSN 1982-7636. pp. 393-436

www.redp.uerj.br

2.3. Antecedentes histórico-institucionais: a adoção automática da tese jurídica e a mitigação do controle difuso de constitucionalidade

Vimos que os julgadores estão vinculados materialmente aos precedentes e que os precedentes, como dispostos pela lei, reclamam enquadramentos típicos aos litígios. Disto concluiu-se uma adesão imediata ao precedente no caso tipificado, sem qualquer sopesamento. Ao julgador caberá verificar, por meio da alteridade, quais dos precedentes no arcabouço preexistente conecta-se ao caso. Tudo isso, obviamente, se existir um precedente adequado. Resta perguntar, então, pela atuação no caso da ausência de precedente base.

O que interessa aqui não é o controle de legalidade do precedente (revisão da tese jurídica, o overruling), mas sim a possibilidade concreta das instâncias ordinárias atuarem por uma eficácia formal ou mesmo material de matiz amplificada dos precedentes na carência do enquadramento típico. Para isso recorda-se que antecede os precedentes o debate sobre a eficácia das decisões proferidas em controle de constitucionalidade, sendo aquele uma espécie de legado deste ${ }^{18}$.

Desde 2006 o Superior Tribunal de Justiça já entendia que as decisões tomadas em plenário pelo Supremo Tribunal Federal, mesmo sobre recursos extraordinários e ações de competência originária, deveriam ser levadas em conta quando dos julgamentos dos casos particulares ${ }^{19}$ - o que ultrapassa a restrição dos precedentes apenas aos acórdãos repetitivos (CPC, art. 332, II). Essa eficácia tornou-se notória com a decisão do Habeas Corpus $\mathrm{n}^{\mathrm{o}}$ 126.292/SP em 17 de fevereiro de 2016. O paciente impetrou o writ perante o Supremo após a ordem de prisão conseguinte à condenação em segundo grau, em substituição aos recursos ordinários e outros cabíveis no processo penal (ou seja, além do Habeas Corpus, uma ação originária, não havia interposição de nenhum recurso dentro do processo originário). Mesmo se tratando de um caso particular, debateu-se a possibilidade ou não do cumprimento da pena condenatória desde a publicação da decisão de segundo grau, inobstante o trânsito em

\footnotetext{
18 BARROSO, Luís Roberto. MELLO, Patrícia Perrone Campos. Trabalhando com uma nova lógica: a ascensão dos precedentes no direito brasileiro, p. 7. Out/16. Disponível em: http://www.conjur.com.br/2016out-28/artigo-barroso-explica-precedentes-cpc-muda-direito. Acesso em 31/01/2017.

${ }^{19}$ Linha inaugurada pelo REsp 819.850/RS, julgado em 01/06/2006.
} 
Revista Eletrônica de Direito Processual - REDP.

Rio de Janeiro. Ano 11. Volume 18. Número 2. Maio a Agosto de 2017

Periódico Quadrimestral da Pós-Graduação Stricto Sensu em Direito Processual da UERJ

Patrono: José Carlos Barbosa Moreira. ISSN 1982-7636. pp. 393-436

www.redp.uerj.br

julgado. O Habeas Corpus não foi concedido. Em seguida os tribunais passaram a decretar a prisão de inúmeros réus já condenados em segunda instância também quando com recursos pendentes nos tribunais superiores (o mais notório foi o de Gil Rugai apenas cinco dias depois da decisão do $\operatorname{STF}^{20}$ ).

A ausência do enquadramento típico não inibiu os tribunais de justiça de extraírem deste precedente a tese jurídica então firmada. $\mathrm{O}$ que se vê no exemplo do Habeas Corpus $n^{\circ}$ 126.292/SP é que a promoção da alteridade não foi utilizada tal qual determinado pelo Código de Processo Civil. A tese jurídica generalizada, para além da dimensão do caso concreto, veio a ser confirmada apenas em 05 de outubro de 2016 pela decisão das ADC's 43 e 44. Ao mesmo tempo, na exigência de equivalência tanto jurídica quanto fática, todos os processos que contassem com recursos próprios, sejam ordinários ou extraordinários, e não ações autônomas, contra a condenação proferida em segunda instância, não poderiam autorizar a ordem de prisão. Poderíamos concluir provisoriamente que na ausência de enquadramento típico ou o julgador vale-se da eficácia material amplificada ou ele negligencia a alteridade, renunciando sua competência difusa do "controle" do precedente em nome do método silogístico. Para encontrar a resposta, precisamos aprofundarmos a conduta institucional dos julgadores brasileiros. Para isto resta-nos analisar, analogicamente, a amplitude do controle difuso de constitucionalidade pelos juízes singulares e tribunais de justiça.

Se de um lado está o controle abstrato de constitucionalidade, exercido exclusivamente pelo Supremo Tribunal Federal (de modo concentrado - Constituição, art. 102), de outro está o controle difuso, competência que espreita a todos aqueles munidos de jurisdição (Constituição, art. $5^{\circ}, \mathrm{XXXV}$ ). Se o controle de constitucionalidade abstrato é a capacidade do julgador afastar a presunção de legitimidade da norma enunciada em lei, declarando-a inválida tout court, no controle difuso esta capacidade acontece perante o litígio atual, declarando a norma inválida para o caso. Outra distinção, negligenciada pela doutrina, entre controle abstrato e controle difuso de constitucionalidade está na iniciativa

\footnotetext{
${ }^{20}$ Ver em http://g1.globo.com/sao-paulo/noticia/2016/02/condenado-pela-morte-do-pai-gil-rugai-tem-prisaodecretada-em-sp.html. Acesso em 02/01/2017.
} 
Revista Eletrônica de Direito Processual - REDP.

Rio de Janeiro. Ano 11. Volume 18. Número 2. Maio a Agosto de 2017

Periódico Quadrimestral da Pós-Graduação Stricto Sensu em Direito Processual da UERJ

Patrono: José Carlos Barbosa Moreira. ISSN 1982-7636. pp. 393-436

www.redp.uerj.br

de sua atividade. $\mathrm{O}$ controle abstrato sempre depende da formulação de um pedido específico de revisão, enquanto o difuso, diante do dever de fundamentação (Constituição, art. 93, IX), nasce da iniciativa do julgador (no caso particular as partes não precisam levantar a inconstitucionalidade das normas debatidas, podendo o juiz fazer isto - CPC, art. $141 \mathrm{c} / \mathrm{c}$ art. $\left.10^{21}\right)$.

O controle abstrato sobrepõe-se à do difuso, não apenas quanto a limitação às partes do processo. $\mathrm{O}$ controle abstrato pode suprir o controle difuso exercido pelos tribunais e juízes singulares a margem de recurso dentro do processo específico. Essa história começa pela Lei 9868/98, com o parágrafo único do seu art. 28, que instituiu às decisões proferidas em sede de ação declaratória de inconstitucionalidade e ação declaratória de constitucionalidade a eficácia contra todos e efeitos vinculante a todo órgão do Estado, seja qual for o órgão que o integre. Os mesmos efeitos foram atribuídos às decisões em arguições de preceito fundamental pelo $\S 3^{\circ}$ do art. 10 da Lei $9882 / 99$ e, por fim, reconhecido a todo controle abstrato praticado pelo Supremo Tribunal Federal pela Emenda n ${ }^{\circ}$ 45/2004, que alterou o art. 103-A da Constituição da República.

Como exemplo histórico encontra-se a declaração de inconstitucionalidade da segunda frase do art. 1-F da Lei 9494/97 pelas ADI’s 4357 e 4425. Aí foi reconhecido que a simples aplicação dos índices da caderneta de poupança sobre os créditos contra a Fazenda Pública não atendida satisfatoriamente a atualização monetária e a aplicação de juros, caracterizando ofensa ao direito fundamental da propriedade. Por cerca de dois anos foi admitido generalizadamente a ineficácia do dispositivo citado e a substituição da indexação da correção monetária pelo IPCA-E, como atesta a decisão do Recurso Especial $\mathrm{n}^{\circ}$ 1.270.439/Pr, recebido como recurso repetitivo pelo Superior Tribunal de Justiça. Contudo, o pedido das ADI's remetia antes ao $\$ 12$ do art. 100 da Constituição, cujo o conteúdo se circunscreve à expedição de precatórios requisitórios. Por esta limitação, o Supremo veio a receber em repercussão geral o Recurso Extraordinário $n^{\circ}$ 870.947/SE para debater a constitucionalidade do mesmo art. 1-F, segunda frase, da Lei 9494 sobre a atualização do

\footnotetext{
${ }^{21} \mathrm{O}$ limite do juízo ao mérito está o pedido, não a fundamentação da decisão, tampouco na procedência ou não da ação.
} 
Revista Eletrônica de Direito Processual - REDP.

Rio de Janeiro. Ano 11. Volume 18. Número 2. Maio a Agosto de 2017

Periódico Quadrimestral da Pós-Graduação Stricto Sensu em Direito Processual da UERJ

Patrono: José Carlos Barbosa Moreira. ISSN 1982-7636. pp. 393-436

www.redp.uerj.br

crédito sobre período anterior à expedição do precatório. Mesmo carecendo de uma ordem de sobrestamento, a partir da recepção do RE $n^{\circ}$ 870.947/SE observou-se ordens de suspensão de feitos nas instâncias ordinárias onde já se tinha como certa a inconstitucionalidade da segunda frase do art. 1-F da Lei $9494^{22}$, não obstante a possibilidade de controle difuso de constitucionalidade ${ }^{23}$. No próprio Supremo encontram-se alguns votos que admitiram a reforma de acórdãos que exerciam o controle difuso para esses demais tempos da exigibilidade (isto é, reestabeleciam a forma anterior da correção contra a Fazenda Pública $)^{24}$.

Para as cobranças contemporâneas às ADI's todo o controle difuso de constitucionalidade foi em vão ${ }^{25}$, e para as novas cobranças os tribunais suspenderam o controle difuso de constitucionalidade. A consequência é a inércia do controle difuso pelos tribunais e juízos singulares e a possibilidade de julgamento de mérito potencialmente inválido sob vestes da legalidade estrita. Qualquer manifestação sobre a inconstitucionalidade de atos normativos realizados por um controle difuso traz consigo uma falsa sensação de instabilidade ao sistema jurídico ${ }^{26}$. A decisão das ADI's bastaria para o reconhecimento da inconstitucionalidade declarada para todos os momentos da exigibilidade do crédito contra a Fazenda Pública? A tese jurídica não atingiria toda a extensão de eficácia da norma analisada? Mesmo que carente vinculação material estrita entre o STF e as instâncias ordinárias, estes estavam ainda autorizados a exercer o controle difuso; mas não o fizeram.

Tanto o exemplo da adesão ao Habeas Corpus $n^{\circ}$ 126.292/SP quando a adesão às ADI's 4357 e 4425 e seu dissentimento quando do Recurso Extraordinário n 870.947/SE

\footnotetext{
${ }^{22}$ STJ, REsp 1.495.146-MG, REsp 1.495.144-RS e REsp 1.492.221-PR, de relatoria Min. Mauro Campbell Marques.

${ }^{23}$ AgRg no REsp 1432087/MG

${ }^{24}$ STF, Rcl 19.050, Rel. Min. Roberto Barroso; Rcl 21.147, Rel. Min. Cármen Lúcia; Rcl 19.095, Rel. Min. Gilmar Mendes.

${ }^{25}$ Esta situação vale para as execuções que estão em curso, seja ela baseada em título judicial (que já contando com coisa julgada material), seja extrajudicial (que pode ou não contar com coisa julgada material em sede de embargos à execução).

${ }^{26}$ RIBAS DE LIMA, Manoel Pedro; GOBBO, Isabela Sens Fadel. A instabilidade institucional do poder judiciário pelo conflito entre controle concentrado de constitucionalidade e controle difuso. In: XII Simpósio Nacional de Direito Constitucional, 2016, Curitiba. XII Simpósio Nacional de Direito Constitucional, 2016.
} 
Revista Eletrônica de Direito Processual - REDP.

Rio de Janeiro. Ano 11. Volume 18. Número 2. Maio a Agosto de 2017

Periódico Quadrimestral da Pós-Graduação Stricto Sensu em Direito Processual da UERJ

Patrono: José Carlos Barbosa Moreira. ISSN 1982-7636. pp. 393-436

www.redp.uerj.br

revelam que há, no cotidiano judiciário brasileiro, uma sobreposição do método silogístico à atividade, digamos, produtiva do julgador (a alteridade para os precedentes). Nestes termos, não se pode fiar na disposição do juiz em encarar o litígio atual como um caso inaudito, como acredita Pugliese ${ }^{27}$. Tempo e esforço confrontam a lógica do enquadramento típico. Enquanto não houver pronúncia dos tribunais superiores sobre o litígio típico enfrentado, não havendo precedente adequado contemporâneo, a maioria dos juízes singulares e tribunais de justiças se valerão de precedentes "maiores" já existentes ${ }^{28}$. As peculiaridades dos casos serão deixadas de lado e a iniciativa da alteridade ignorada. Não se promove a isonomia, mas a uniformização ${ }^{29}$. O enquadramento típico, embora difere da súmula vinculante, com ela se assemelha por seu instrumento de pretensão silogística - ou seja, não por sua instituição, mas por sua estrutura e eficácia ${ }^{30}$.

\subsection{Unidade ou sistematização cerrada do ordenamento}

Tomada a eficácia vertical dos precedentes pelas delimitações legais, não se pode falar ainda na percepção do ordenamento jurídico como totalidade. Pelo estabelecimento das teses jurídicas como enquadramentos típicos os precedentes promoverão, em sua eficácia, a

\footnotetext{
${ }^{27}$ PUGLIESE, William. Precedentes e a civil law brasileira: interpretação e aplicação do novo código de processo civil. São Paulo: Revista dos tribunais, 2016, p. 60.

${ }^{28}$ É pragmaticamente descartada uma classificação da eficácia dos precedentes baseada na possibilidade ou não de reclamação contra a decisão que desatende os precedentes (eficácia meramente persuasiva, eficácia normativa e eficácia intermediária dos precedentes), como descrito em BARROSO, Luís Roberto. MELLO, Patrícia Perrone Campos. Trabalhando com uma nova lógica: a ascensão dos precedentes no direito brasileiro, p. 13. Out/16. Disponível em: http://www.conjur.com.br/2016-out-28/artigo-barroso-explicaprecedentes-cpc-muda-direito. Acesso em 31/01/2017. Ainda que não se possa interpor reclamação contra decisão que desrespeita decisão de recurso especial e/ou extraordinário não tido como repetitivo, caberá a interposição dos recursos especial e/ou extraordinários eles mesmos. Tal classificação é paliativa, ainda que correta em termos exegéticos, pois não tira a eficácia (exatamente por ser eficácia, e não aplicação) material dos precedentes não-repetitivos.

${ }^{29}$ FOUCAULT, Michel. Vigiar e punir: nascimento da prisão. Trad. pr. Raquel Ramalhete. 42a ed. Petrópolis: Vozes, 2014, p. 240.

${ }^{30}$ A súmula, e assim o enquadramento típico, distancia-se, como aponto Abboud sobre as súmulas, da tradição do common law e aproxima-se dos assentos portugueses. No art. $2^{\circ}$ do Código Civil português autorizava-se os tribunais à formularem proposições (os assentos) com força obrigatória geral. Destaca-se que esta competência para os assentos foi declarada inconstitucional por violação do art. 115/2 de sua Constituição portuguesa (que trazia a figura do plebiscito). Isto é trazido por ABBOUD, Georges. Súmula vinculante versus precedentes: notas para evitar alguns enganos; in: WAMBIER, Teresa Arruda Alvim (Coord.). Revista de Processo. Nov/2008. Ano 33. n. 165. São Paulo: Revista dos tribunais, 2008, p. 227.
} 
Revista Eletrônica de Direito Processual - REDP.

Rio de Janeiro. Ano 11. Volume 18. Número 2. Maio a Agosto de 2017

Periódico Quadrimestral da Pós-Graduação Stricto Sensu em Direito Processual da UERJ

Patrono: José Carlos Barbosa Moreira. ISSN 1982-7636. pp. 393-436

www.redp.uerj.br

sistematização mecânica do Direito. Os precedentes estenderiam a previsibilidade normativa sempre dentro dos conteúdos das normas já positivadas. Haveria antes uma taxinomia dos conteúdos normativos, tal qual na biologia, classificando e conectando meticulosamente inúmeros tipos sem jamais negar a possibilidade de um novo tipo ou mesmo uma outra linha de gêneros.

A pretensão da unidade revela-se antes na inércia dos juízes singulares e dos tribunais de justiça em sobrepor o método analítico à análise da alteridade. $\mathrm{O}$ reconhecimento de antinomias e zonas cinzentas, isto é, de lacunas normativas, é negada. Mas a pretensão é frustrada. Busca-se, antes, assegurar resultados ${ }^{31}$. Persiste o pensamento econômico moderno. Isso não torna o Direito um todo, pois não há síntese. O que ocorre é o fechamento mecânico do sistema.

Esse fechamento é parcial. A mecânica desvelada não alcança os tribunais superiores, que ainda possuem a competência de inovação da tese jurídica: um caminho sempre aberto dentro do sistema, possibilitando uma reestruturação da taxionomia normativa vigente sobre as instâncias ordinárias. O fechamento, todavia, é verdadeiro estaticamente no julgamento do litígio atual nas instâncias ordinárias, submissas aos precedentes préexistentes.

Essa vinculação, ressalta-se, vige apenas em termos de eficácia. Por mais que a estrutura normativa institucional volte-se no sentido descrito de atuação, ela não necessariamente irá acontecer - nada mais natural à sua base normativa ${ }^{32}$. Outros modos de

\footnotetext{
${ }^{31}$ Ver PUGLIESE, William. Precedentes e a civil law brasileira: interpretação e aplicação do novo código de processo civil. São Paulo: Revista dos tribunais, 2016, p. 18. E neste pondo deve-se evitar a confusão de Mitidiero. Segundo ele, a previsibilidade do resultado garantiria liberdade. MITIDIERO, Daniel. Precedentes: da persuasão à vinculação. 2 ed. São Paulo: Revista dos Tribunais, 2017, p. 22. A previsibilidade do resultado é, no entanto, demanda da soberania. A necessidade de confirmar a vontade é a do soberano. E o soberano não suporta a convivência com outros soberanos (direitos como âmbitos negativos de atuação). Ele precisa exercer domínio (daí sua imperatividade). A liberdade, se realmente política, pressupõe a convivência. Política é pluralidade. Não basta pensar nos outros; não se vive sozinho no mundo. Pluralidade é fato. E convivência representa, sob a ótica da vontade, o risco de interferência e deformação do resultado. Liberdade é, politicamente, incerteza. Daí a importância da norma em prover estabilidade - numa relação contraditória com a liberdade (tutelando contra suas ameaças mas jamais garantido ou a estimulando), mas certamente dependente das disposições recíprocas espontâneas para refreamento prospectivo.

${ }^{32}$ É da normatividade ser vinculativa tanto quanto não necessária. Toda proposição normativa, por ser norma, tenciona, de vários modos, o destinatário ao atendimento dela. Nenhuma pessoa ou instituição precisa, inevitavelmente, cumprir a norma. Toda norma pode ser descumprida. Por mais vinculativa que seja, toda norma sofre da hesitação no seu cumprimento. Ver KELSEN, Hans. Teoria pura do Direito. Trad. de João
} 
Revista Eletrônica de Direito Processual - REDP.

Rio de Janeiro. Ano 11. Volume 18. Número 2. Maio a Agosto de 2017

Periódico Quadrimestral da Pós-Graduação Stricto Sensu em Direito Processual da UERJ

Patrono: José Carlos Barbosa Moreira. ISSN 1982-7636. pp. 393-436

www.redp.uerj.br

atuação podem se abrir, não só pela consciente infração do método imposto mas também pela antinomia legal objeto deste estudo. A eficácia vertical dos precedentes depara-se com o exame de ponderação.

\section{PONDERAÇÃO E O CASO CONCRETO COMO FATOR EFETIVO DA DECISÃO}

Logo no início do Código de Processo Civil depara-se com a exigência de consideração da diversidade de fatores na tomada da decisão judicial. No art. $8^{\circ}$ desta lei estão enumerados alguns, determinando também como isso deve acontecer. Ordenamento jurídico, fins sociais, bem comum e dignidade da pessoa devem ser levados em conta dentro da proporcionalidade, da razoabilidade, da legalidade, da publicidade e da eficiência. São fatores e técnicas a serem equilibrados uns aos outros; equilíbrio atingido pelo exame de ponderação.

A ponderação surge da crítica pós-guerra ao positivismo. De um lado, regimes totalitários revelaram que o simples fato de seguir as normas positivas não pode dispensar o exame da ação. Se ideologia, segregação e terror forem regras, a dignidade passa a ser exceção e atrocidades seriam juridicamente aceitas. De outro lado está a incomunicabilidade imediata entre norma jurídica e ação ${ }^{33}$ - uma crítica muito mais antiga. Ao propor uma posição ou ação, a norma está desconectada do cotidiano do ato já praticado ou a ser praticado. $\mathrm{O}$ conteúdo da norma, por mais específico que seja, sempre é abstrato. $\mathrm{O}$ ato, além das peculiaridades, conta com uma história, um contexto próprio. $\mathrm{O}$ ato é, com sua dose de contingência, concreto. A aplicação da norma ao litígio atual por um método analítico, a conformidade por verossimilhança contrafática, representa necessariamente distorção da norma ou do caso, senão de ambos.

\footnotetext{
Baptista Machado. 6. ed. São Paulo: Martins Fontes, 1998. p. 84. Se a própria normatividade é incapaz de manter a segurança, uma vez que sempre pressupõe a possibilidade de infração (liberdade), então a eficácia dos precedentes depende antes de uma atitude política de comprometimento institucional entre os membros do judiciário (como acontece na common law) do que do art. 927 do Código de Processo Civil.

${ }^{33}$ AUGSBERG, Ino. A desumanidade da razão na multiplicidade de suas vozes: a teoria da ponderação e a sua crítica como um programa jurídico-teórico; in: (Org) CAMPOS, Ricardo. Crítica da Ponderação: método constitucional entre a dogmática jurídica e a teoria social. São Paulo: Saraiva, 2016, p. 21.
} 
Revista Eletrônica de Direito Processual - REDP.

Rio de Janeiro. Ano 11. Volume 18. Número 2. Maio a Agosto de 2017

Periódico Quadrimestral da Pós-Graduação Stricto Sensu em Direito Processual da UERJ

Patrono: José Carlos Barbosa Moreira. ISSN 1982-7636. pp. 393-436

www.redp.uerj.br

No Brasil, a ponderação adentra pela apropriação de teorias estrangeiras por acadêmicos em programas de intercâmbio. Em meados da década de 1990 surgem aqui as primeiras referências à concepção de princípios de Ronald Dworkin e à tradução desta para a linha continental por Robert Alexy. A partir do início dos anos 2000 surgiu no país a exigência pelo exercício de ponderação nos litígios que envolviam direitos fundamentais ${ }^{34}$. Esta postura não decorre imediatamente da Constituição de 1988, mas sim da teoria dos princípios.

3.1. Teoria dos princípios como prelúdio à ponderação

Com a recepção da teoria de Dworkin pela corrente continental, e não no Dworkin ele mesmo, observa-se o questionamento da estrutura da norma. A distinção entre princípios e regras foi o primeiro passo. A exemplo de Humberto Ávila, distingue-se uma e outra modalidade de norma através da dicotomia deôntico-teleológica, reconhecendo nos princípios metas, e deôntico-deontológico, colocando regras como mandamentos categóricos ${ }^{35}$.

Princípios são concebidos como razões e fundamentos, ganhando uma dimensão de peso sobre o julgamento das ações. Os princípios vêm em justificação do ato. Com Alexy, que visava dar sustento positivo aos princípios de Dworkin, as normas constitucionais, principalmente aquelas arroladas dentre os direitos e garantias fundamentais, passam a figurar como "ordem objetiva de valores" - expressão do Tribunal Constitucional Federal alemão.

Se princípios vem para justificar, fundamentações não existem por si só. Princípios demandam por eventos a serem fundamentados. No entanto, a estrutura desta norma não comporta a descrição de uma conduta ou situação específica. A primordialidade inata do

\footnotetext{
${ }^{34}$ Primeira citação de Alexy aconteceu no STF pelo Rcl 2234 MG, de Relatoria do Min. Gilmar Mendes, julgado em 20/03/2003, e pelo MS 24547, de Relatoria da Min. Ellen Gracie, julgado em 14/08/2003; já Dworkin foi citado inicialmente pelo STF no HC 84025 de Relatoria do Min. Joaquim Barbosa, julgado em 04/03/2004, e na ADI 2548, de Relatoria de Min. Gilmar Mendes, julgado em 18/10/2005.

${ }^{35}$ ÁVILA, Humberto. Teoria dos Princípios: da definição à aplicação dos princípios jurídicos. $11^{\mathrm{a}}$ ed. São Paulo; Malheiros, 2010, p. 63.
} 
Revista Eletrônica de Direito Processual - REDP.

Rio de Janeiro. Ano 11. Volume 18. Número 2. Maio a Agosto de 2017

Periódico Quadrimestral da Pós-Graduação Stricto Sensu em Direito Processual da UERJ

Patrono: José Carlos Barbosa Moreira. ISSN 1982-7636. pp. 393-436

www.redp.uerj.br

princípio faz dele uma pretensão global. Todo princípio, reclamando o papel de fundamento, recorre incidir sobre o maior número de casos possíveis. E não existe apenas um princípio. Um mesmo caso estará aberto a mais de um princípio. Vale dizer: do mesmo modo que um caso pode suportar várias decisões, e se uma mesma decisão pode receber diversos fundamentos, se faz iminente o confronto entre fundamentos. Não há princípio mais importante que outro. E, mesmo que suposta certa hierarquia normativa entre princípios, a antinomia entre princípios não se resolve em $\mathrm{si}^{36}$.

Imagine a seguinte hipótese: descobre-se a troca de crianças no hospital após seis anos dos partos. O Estatuto da Criança e Adolescente firma que toda criança deve ser criada por sua família natural (art. 25 c/c 39). A relevância desta norma está na proclamação de categorias tradicionais (não obstante hoje a tradição já esteja rompida) com a reverência aberta ao direito de toda pessoa a conhecer suas origens biológicas (ECA, art. 48), não obstante a vedação de discriminação (C. Civil, art. 1.596). Alimenta-se a crença de que estas origens engendrariam, como raízes sustentam as árvores, a personalidade (Constituição, art. $\left.226, \S 7^{\circ}\right)$. Em outras palavras, o compasso ascendência-descendência atuaria como força formadora de caráter individual (onde a figura dos pais, e os pais destes, impulsionariam o indivíduo em suas ações) $)^{37}$. Por outro lado, já é de se esperar vinculação afetiva profunda entre criança de identificação falha com as pessoas que a receberam após mais de seis anos de convívio. E a paternidade afetiva também é reconhecida (embora ainda não esgote a paternidade biológica ${ }^{38}$ ). Aparece como questão, então, o melhor “interesse” para a criança: permanecer com a família afetiva ou ser entregue aos seus pais biológicos? Origens vs. afeto. O juiz que receber este caso não poderá resolver em tese este litígio: a paternidade afetiva e origem biológica não se sobrepõe uma a outra, e, nesse conflito, nada dizem sobre o melhor interesse para a criança. A superação da ordem biológica não afasta a possibilidade de incompletude da afetividade, como a superação da paternidade afetiva não significa o resgate

\footnotetext{
${ }^{36}$ ALEXY, Robert. Teoría de los derechos fundamentales. Trad. esp. Ernesto Garzón Valdés. Madrid: Centro de Estudios Políticos y Constitucionales, 2002, p. 157.

37 A permanência da criança identificada erroneamente com outras pessoas que não seus pais biológicos resultaria, normativo-positivamente falando, em adoção à brasileira.

${ }^{38}$ Ver STJ, AgRg no REsp 1319721/RJ, Rel. Ministro ANTONIO CARLOS FERREIRA, QUARTA TURMA, julgado em 07/04/2016, DJe 12/04/2016. Hoje a questão é tema em repercussão geral pelo RE 898.060 no Supremo Tribunal Federal (Tema 622).
} 
Revista Eletrônica de Direito Processual - REDP.

Rio de Janeiro. Ano 11. Volume 18. Número 2. Maio a Agosto de 2017

Periódico Quadrimestral da Pós-Graduação Stricto Sensu em Direito Processual da UERJ

Patrono: José Carlos Barbosa Moreira. ISSN 1982-7636. pp. 393-436

www.redp.uerj.br

de uma paternidade pela linha natural (pois, embora biológica, nunca teria sido exercida até então).

Dois aspectos chamam a atenção aqui. O primeiro é que todo caso é passível da incidência de mais de um princípio. Isto porque o princípio, por sua estrutura otimizável, estende-se de forma incerta. Da mesma forma que todo argumento encontra um contraargumento, o caso sempre envolverá, no mínimo, duas colocações principiológicas potencialmente opostas. O segundo aspecto, de interesse essencial a este trabalho, é que sempre será o próprio caso a última razão em jogo para a resolução do litígio, como exposta pela lei da colisão de Alexy (ideia presente no CPC, art. $489, \S 2^{\circ}$ ). No exemplo dado, serão as melhores condições para a formação da criança, se dos pais biológicos ou dos pais afetivos, que direcionará o julgamento.

Hoje aceita-se a possibilidade de ponderação não só entre princípios, mas também entre regras, como argumenta Humberto Ávila. E resgatando a ideia de que a sentença do processo é juridicamente constitutiva, encontra-se em Luiz Guilherme Marinoni a afirmação de que a norma é o resultado da conjunção entre o sentido do enunciado ao caso concreto ${ }^{39}$ (ideia presente no CPC, art. 489, $\S 1^{\circ}$, I, II e III). Há uma sopesagem entre normas para verificar qual atende melhor os interesses em jogo, qual tem maior peso no caso concreto. Com efeito, ou é superada o entendimento mais simples do enunciado (elevando a norma para outros patamares), ou a norma passa a ser insuficiente para o julgamento.

3.2. A abertura do discurso normativo ao litígio atual

Colocou-se, como pressuposto, a identidade de casos para a eficácia dos precedentes, tal qual delineada pelo Código de Processo Civil vigente e esboçada pela história institucional recente do Poder Judiciário brasileiro. Por ser tido como idêntico ao caso que originou o precedente, deste o litígio atual poderia emprestar a decisão. Com a definição de enquadramentos típicos torna-se possível uma taxionomia normativa

\footnotetext{
${ }^{39}$ MARINONI, Luiz Guilherme. Teoria geral do processo. Vol.1. $7^{\text {a }}$ ed. São Paulo: Revista dos Tribunais, 2013, p. 98. No mesmo sentido MITIDIERO, Daniel. Precedentes: da persuasão à vinculação. 2 ed. São Paulo: Revista dos Tribunais, 2017, p. 78.
} 
Revista Eletrônica de Direito Processual - REDP.

Rio de Janeiro. Ano 11. Volume 18. Número 2. Maio a Agosto de 2017

Periódico Quadrimestral da Pós-Graduação Stricto Sensu em Direito Processual da UERJ

Patrono: José Carlos Barbosa Moreira. ISSN 1982-7636. pp. 393-436

www.redp.uerj.br

provisoriamente fechada. Em sentido oposto, para o exercício da ponderação parte-se do pressuposto que todo litígio é singular, e que tal singularidade seria o principal fator em jogo, pois não existe nenhum caso igual à ele. Neste primeiro momento analisaremos uma questão metodológica, que se traduz na pergunta se pode haver ou não enquadramento típico na ponderação, e, depois, porque se pressupõe a singularidade de cada caso.

A colocação do litígio atual como fator para a decisão não representa a impossibilidade imediata de presumir casos idênticos, como supõem os efeitos verticais dos precedentes. O litígio, mesmo ao método analítico mais estreito, sempre é um fator básico: a peça sobre a qual se ajustava a norma abstrata. Se fosse possível ter a ponderação como uma espécie de aplicação, onde norma rotularia juridicamente o fato, não obstante a infinidade de fatores, nada se poderia opor à convivência entre ela e os efeitos verticais dos precedentes. A diferenciação entre fato e norma é a de momentos numa relação estatística: a norma prevê o fato e aguarda o acontecimento deste, determinando desde o início as consequências.

O método analítico coloca, contudo, a resposta antes do problema. O que está em jogo aí não são os litígios tampouco os litigantes. Nada do que tenha sido feito pelos litigantes será bom ou mau. O que há é o processo de aplicação por um juízo determinante e o seu coroamento com a imputação. Toda ação passa a ser produto da previsão normativa. Pouco importa a dimensão da previsão: ela pode ser a mais ampla possível ou a mais estreita e selecionada. Haverá apenas diferentes unidades dentro de um critério de mensuração. Seja qual for a diferente dimensão, normas legais ou precedentes, a medida sempre é algo externo ao que é medido - recorda-se do paradoxo entre regra e equidade em Aristóteles ${ }^{40}$. Estaticamente, abstrato transcende concreto; dinamicamente, o genérico sobrepõe-se ao particular.

Para a ponderação, é do caso que surge a solução. Trata-se de uma questão de lógica: o litígio inaugura o problema a ser solucionado. Sendo o termo inicial a formulação do problema, assim como controvertido pelas partes e pelo juiz (CPC, art. $9^{\circ}, 10$ e $489, \S^{\circ}$,

\footnotetext{
40 ARISTÓTELES. Ética a Nicômaco. Trad. pt. Mário da Gama Kury. $3^{\text {a }}$ Ed. Brasília: Editora Universidade de Brasília, 2001, p. 109 [1137b].
} 
Revista Eletrônica de Direito Processual - REDP.

Rio de Janeiro. Ano 11. Volume 18. Número 2. Maio a Agosto de 2017

Periódico Quadrimestral da Pós-Graduação Stricto Sensu em Direito Processual da UERJ

Patrono: José Carlos Barbosa Moreira. ISSN 1982-7636. pp. 393-436

www.redp.uerj.br

IV), forma-se uma estrutura dialética onde uma relação continuada entre pessoas visa, por meio de argumentos e persuasão, unicamente à solução do litígio. Não há surpresa se todas as cartas forem postas na mesa $\left(\mathrm{CPC}\right.$, art. $7^{\circ}$ e $\left.9^{\circ}\right)$. O contraditório impregna a prestação jurisdicional com uma miscelânea de critérios e motivos (mas sempre, se pautados pela franqueza, relativos ao caso concreto), participando indiretamente da decisão.

Tenha-se em mente apresentações de peças teatrais. Semelhante a todo litígio, ela relata uma trama entre os personagens. Este relato corresponde não só circunstância fática do litígio, mas também a do contraditório, pois é do personagem expor suas razões. E mais. Como na leitura de um romance ou no assistir à uma peça de teatro, onde cada capítulo e cada ato constrói narrativamente o espetáculo da sua abertura até sua conclusão, o processo coloca o caso entre parênteses. A decisão é o termo final, como a moral no desfecho de cada história. Com um começo e um fim para o litígio, isto é, do evento que se traduz na causa de pedir remota da ação até o julgamento, é possível abarcar o caso como se fosse um todo (um todo ambivalente que se manifesta antes ao julgador do que no próprio episódio). Na medida que esse todo, por mais equívoco que seja, se revela, nele encontra-se respostas.

O caso concreto não é entendido como um fator entre outros. Os fatores são relacionados entre si, entre si, são relacionados, como relata Ferraz Júnior, dialeticamente ${ }^{41}$. O caso concreto é o corpo. Trata-se de um todo acima da soma das partes. As descrições dos atos e fatos em jogo são amealhadas no processo em mesmo patamar que os argumentos de cada uma das partes, que os do próprio juiz, que o ordenamento jurídico, e assim por diante. Essa síntese desfaz a ideia de aplicação. E o todo passa a ser um fim em si mesmo, estando já contido nele o seu significado (sem vínculos com outros julgamentos). Dessa nova objetividade pleiteia-se um conteúdo significativo de modalidade deôntico-ético (válido não significa mais agir estritamente conforme a prescrição legal, senão em homenagem à legalidade). Refuta-se, numa postura analítica, a fronteira normativa ao suporte fático como conduta. Não se pergunta mais o dever-ser, enquanto um tipo.

A constatação imediata do exame de ponderação é a circunscrição do discurso normativo. Como postulado, e essa é outra hipótese basilar deste trabalho, a ponderação é

\footnotetext{
${ }^{41}$ FERRAZ JUNIOR, Tércio Sampaio. A ciência do direito. $2^{\text {a }}$ Ed. São Paulo: Atlas, 1986, p. 19.
} 
Revista Eletrônica de Direito Processual - REDP.

Rio de Janeiro. Ano 11. Volume 18. Número 2. Maio a Agosto de 2017

Periódico Quadrimestral da Pós-Graduação Stricto Sensu em Direito Processual da UERJ

Patrono: José Carlos Barbosa Moreira. ISSN 1982-7636. pp. 393-436

www.redp.uerj.br

metanormativa, jamais normativa. Não há nem espaço para a concepção contrafática e sua projeção de conduta, tampouco à manifestação de uma premissa a priori. O exame de ponderação desprende decisão da manifestação normativa. Isso faz com que o ordenamento jurídico, seja ele uma totalidade, seja ele um sistema fechado, não se coloque como causa eficiente da decisão, senão uma entre várias. A imparcialidade não mais se comunica com objetividade. $\mathrm{O}$ ato de fundamentar não é mais explicar a incidência da norma ao fato (não obstante o termo usado nos inc. I e II do $\S 1^{\circ}$ do art. 489 do CPC). Necessariamente, sob a perspectiva do ordenamento, o exame de ponderação gera uma cisão. A decisão, embora se faça norma às partes do processo, não é norma em medida alguma. Ela é produto da relação entre o litígio e o julgador aberto a compreender o litígio.

É preciso que seja aceito, no julgamento de cada litígio, um exame livre, aberto e franco, sempre pondo em xeque todos os preceitos existentes (a norma positiva - legal ou jurisprudencial -, o pensamento tradicional e, até mesmo, a autoridade do julgador). As únicas quaestiones juris, no seu sentido tradicional, serão a competência institucional do julgador (Constituição, art. $5^{\circ}, \mathrm{XXXV}$, e CPC, art. $3^{\circ}$ ) e a obrigação deste em proferir uma decisão ao caso (CPC, art. $4^{\circ}$ c/c 317).

\subsection{A singularidade do litígio atual para a ponderação}

Duas conclusões prévias podem ser retiradas até aqui. Primeiro: há uma distinção de método que impede a sintonia entre exame de ponderação e eficácia vertical dos precedentes. Todavia ainda que não se pode dizer que não existam litígio iguais, mas sim, e essa é a segunda conclusão prévia, que o método analítico, que faz da norma previsão da ação, nega a possibilidade da existência de situações particulares. Precisa-se ir mais a fundo. Só na constatação da singularidade do caso poder-se-á concluir que cada decisão deve ser única.

Toda interpretação de uma mesma peça é singular: mesmo roteiro, mesmas falas, mas espetáculos totalmente diferentes um dos outros. E existe uma ironia ainda maior: a diversidade de espectadores. Mesma atuação, opiniões diferentes. Essa segunda ironia coloca-se juridicamente como uma questão de legitimidade mas que, embora interrogue a 
Revista Eletrônica de Direito Processual - REDP.

Rio de Janeiro. Ano 11. Volume 18. Número 2. Maio a Agosto de 2017

Periódico Quadrimestral da Pós-Graduação Stricto Sensu em Direito Processual da UERJ

Patrono: José Carlos Barbosa Moreira. ISSN 1982-7636. pp. 393-436

www.redp.uerj.br

competência dos tribunais superiores para a formulação dos precedentes como a do juiz monocrático para julgar o caso, não tem espaço neste trabalho. A singularidade do espetáculo é o que nos preocupa.

Esta questão é relevante pois parece ser ela que responderá "Como evitar que se comprometa indesejavelmente o princípio da isonomia, como decorrência da possível diversidade de decisões, que podem ser geradas pelo uso de parâmetros menos seguros do que a lei escrita [norma jurídico positiva]?" formulada por Teresa Arruda Alvim Wambier ${ }^{42}$.

A singularidade que nos referimos não se trata de um jogo de fatores. Se pensarmos que a decisão seja o resultado de inúmeros fatores, também deve se pensar que cada um destes fatores é passível de variáveis. Atores, atuações, direções, narrativas diferentes... Com efeito, ainda que se delineie um caso com todos os mesmos fatores, a variação de apenas um é suficiente para que a decisão se distinga. Mas decisão distinta não significa ainda única.

Temos duas premissas que, associadas, superam esse cálculo de probabilidade. São elas contingencialidade e finitude do julgador. A primeira firma que, embora todo efeito seja precedido de uma causa, nada confirma que toda potencial causa provoque o mesmo efeito (se é que provoca efeito), bem como nada confirma que o efeito decorre exclusivamente de determinada causa. Portanto a descrição estática do conflito de interesses não assegura um entendimento dinâmico, e histórico, do caso - principalmente quando culpa (empírica) e responsabilidade (jurídica) são categorias básicas. A segunda impõe o reconhecimento de que o(s) observador(es) não pode(m) abarcar todas as causas em jogo; logo, ainda que se possa firmar que tal evento seja um efeito (o que, de certo, é), ainda assim, nada assegurará ao observador todas as causas que o desencadearam. Se verdadeiras estas premissas, nada autoriza ao julgador delinear de modo definitivo o caso $^{43}$. Sempre haverá algo a ser revelado (tanto fática quanto juridicamente). E diante desta sina, nada parece pressupor que este e aquele caso sejam iguais (senão a ignorância). Inverte-se o ônus: caberá tal demonstração, se possível, a quem firma que há casos idênticos.

\footnotetext{
${ }^{42}$ WAMBIER, Teresa Arruda Alvim. Estabilidade e adaptabilidade como objetivos do direito: civil law e common law; in Revista de Processo. Vol. 172. Jun/2009, p. 121 (p. 3).

${ }^{43}$ JASPERS, Karl. Origen y meta de la historia. Trad. Fernando Vela. $4^{\circ}$ ed. Madrid: Revista de Occidente, 1968 , p. 242.
} 
Revista Eletrônica de Direito Processual - REDP.

Rio de Janeiro. Ano 11. Volume 18. Número 2. Maio a Agosto de 2017

Periódico Quadrimestral da Pós-Graduação Stricto Sensu em Direito Processual da UERJ

Patrono: José Carlos Barbosa Moreira. ISSN 1982-7636. pp. 393-436

www.redp.uerj.br

Também pode ser colocado que, embora as leis físicas possam se repetir, o evento, quando visto como história, não recomeça. Condições históricas não se reproduzem, fazendo que cada evento aconteça uma vez e nunca mais se apresente de novo. A história não seria regida por leis, senão formada por fatos particulares, com circunstâncias tão particulares quanto $^{44}$. Assim, a Primeira Guerra Mundial aconteceu uma vez e não se repetiu na Segunda (o que revela ser a totalidade do caso concreto uma questão jurígena: na facticidade nenhum evento tem um começo e um fim determinado). Pela historicidade, reclama-se por algo que não faz parte da materialidade dos litígios. A sua paisagem não afeta por si; é preciso certo peso, para além do "dado" normativo, que reclama a atenção do espectador ${ }^{45}$. É apenas com o testemunho do processo que a quintessência do litígio se revela.

Para a ponderação é preciso considerar o firmamento do caso particular. Ao colocálo entre parênteses, o processo faz do caso único, indiferente aos contextos maiores. Tirar do jogo causas e efeitos traduz-se juridicamente em retirar-se de uma lógica de imputação, no seu sentido kelseniano. Não importa a sequência de razões anteriores, tampouco a repercussão externa das suas próprias razões. O caso abre novos horizontes para si. A própria condição do exame de ponderação pressupõe que o caso é único. A tarefa do juiz não é concluir a partir dos fatos, mas estabelecer, na sua imersão no processo e no contraditório deste, a materialidade dos fatos e daí tirar suas conclusões ${ }^{46}$ - uma vez que os fatos já se foram e deles restam provas (em boa parte das vezes insatisfatórias). Portanto o exame de ponderação não exige uma decisão única (admitindo diversas possibilidades de decisão ao mesmo caso), senão concebe a decisão proferida como única.

Enquanto o discurso normativo, incluindo nele os efeitos verticais dos precedentes, vê a insegurança como a premissa a ser superada (pela unidade do ordenamento), ponderação não elimina a insegurança ${ }^{47}$, senão abraça-a como ônus (tomando a norma com outros olhos).

\footnotetext{
${ }^{44}$ BERGSON, Henri. A energia espiritual. Trad. Rosemary Costhek Abílio. São Paulo: Editora WMF Martins Fontes, 2009, p. 64.

${ }^{45}$ BENJAMIN, Walter. A obra de arte na era de sua reprodutibilidade técnica, in Magia e técnica, arte e política: ensaios sobre literatura e história da cultura. $8^{a}$ Ed. São Paulo: Brasiliense, 2012, p. 182.

${ }^{46}$ GOODHART, Arthur L. Determining the racio decidendi of a case; in The Yale Law Journal. Vol. 40. N.

2. Dez. 1930, p. 169. Disponível em: http://www.umiacs.umd.edu/ horty/courses/readings/goodhart-1930ratio.pdf. Acesso em 02/03/2017.

$\overline{47}$ Conclusão semelhante, mas atingida por outros meios ver AUGSBERG, Ino. A desumanidade da razão na multiplicidade de suas vozes: a teoria da ponderação e a sua crítica como um programa jurídico-teórico; in:
} 
Revista Eletrônica de Direito Processual - REDP.

Rio de Janeiro. Ano 11. Volume 18. Número 2. Maio a Agosto de 2017

Periódico Quadrimestral da Pós-Graduação Stricto Sensu em Direito Processual da UERJ

Patrono: José Carlos Barbosa Moreira. ISSN 1982-7636. pp. 393-436

www.redp.uerj.br

Nesse conflito metodológico conclui-se que eficácia dos precedentes e exame de ponderação sustentam-se, cada uma, em premissas diametralmente opostas. E, como tal, os resultados também serão diferentes. Possuindo validade limitada apenas a si, a decisão resultante da ponderação serviria apenas como exemplo - aí vigendo sob o âmbito formal da eficácia de precedentes. O exemplo circunscreve-se a si, mas, pela sua condição exemplar, sempre espelharia algo de geral $^{48}$. Apesar de sua particularidade, o litígio concreto e seu julgamento exemplifica a manifestação de algum princípio (no sentido de Dworkin). Ele nunca revelará a sina do julgamento, senão lançará luz ao esforço tanto argumentativo quanto crítico do julgador. O precedente, então, atuaria apenas como tertium comparationis. Podendo o julgador ponderar o precedente e mediá-lo perante o caso concreto, a força normativa não estaria no precedente ele mesmo ${ }^{49}$ senão, eventualmente, no dever do julgador em revisar a história institucional do tribunal que integre. O julgamento permanecerá circunscrito ao caso - por isso sempre repelirá uma eficácia material dos precedentes -, mas sempre trará uma carga instrutiva da justiça.

De tudo isso percebe-se que nenhum dos dois postulados interroga a questão se haver ou não casos iguais. Se o cotidiano dos julgamentos aponta casos iguais, senão muito semelhantes no que lhes funda, a razoabilidade nos guia em sentido contrário. Os pressupostos da singularidade de todo caso são efetivamente mais palpáveis e concretos do que a da identidade passível de projeção de uma sobre a outra. Não faz sentido, numa realidade baseada em particularidades, como se coloca cada litígio, assumir a partir deles afirmações universais. As universalidades degeneram-se em vagueza. A pergunta sobre a justiça deve ser renovada a cada caso ${ }^{50}$.

(Org) CAMPOS, Ricardo. Crítica da Ponderação: método constitucional entre a dogmática juríudica e a teoria social. São Paulo: Saraiva, 2016, p. 31.

${ }^{48}$ ARENDT, Hannah. Liçoes sobre a filosofia política de Kant. Trad. de André Duarte de Macedo. $2^{\mathrm{a}}$ ed. Rio de Janeiro: Relume-Dumará, 1994, p. 77.

${ }^{49}$ Motivo para alguns distinguir precedente de exemplo. SCHAUER, Frederick. Thinking like a lawyer. Cambrigde: Harvard University Press, 2009, p. 38-41 apud MITIDIERO, Daniel. Precedentes: da persuasão à vinculação. 2 ed. São Paulo: Revista dos Tribunais, 2017, p. 35, nota 56.

${ }^{50}$ RIBAS, Christina Miranda. Justiça em tempos sombrios: A justiça no pensamento de Hannah Arendt. Ponta Grossa: Editora UEPG. 2005, p. 163. 
Revista Eletrônica de Direito Processual - REDP.

Rio de Janeiro. Ano 11. Volume 18. Número 2. Maio a Agosto de 2017

Periódico Quadrimestral da Pós-Graduação Stricto Sensu em Direito Processual da UERJ

Patrono: José Carlos Barbosa Moreira. ISSN 1982-7636. pp. 393-436

www.redp.uerj.br

3.4 Críticas ao exercício da ponderação no Brasil e o ponto-cego do neoconstitucionalismo

A superação do enunciado normativo, senão da própria norma, tem gerado certo constrangimento. Encontram-se decisões que não possuem sustento em enunciado algum (exemplo da descriminalização do aborto no caso de feto anencefálico) até a situações que rompem com normas positivas (o caso da prisão após a decisão em segunda instância). Estas decisões certamente atendem demandas sociais, mas estão, de todo modo, a margem de assento legal (senão jurisprudencial) prévio. Surgem denúncias contra o excesso no ativismo judiciário, taxando-o pejorativamente de ponderação à brasileira, como encontramos nos artigos de Lenio Streck ${ }^{51}$. De fato, o judiciário sai da sua posição de expectador, ocupada de direito e por tradição, para a posição de ator, hesitante nesse papel. E parece haver dois fatores que explicam esse excesso.

A primeira explicação está na concepção de ponderação. Pois bem, se correto que cada situação é única e não é passível de repetição, então está aberta uma porta para ultrapassar a própria condição apriorística da norma - o que explica o excesso denunciado. Isso não retira de Streck o mérito de denunciar o abuso da ideia de interpretação. Mas esta questão não se encerra na formulação da ponderação, senão acontece em razão da própria estrutura normativa dos princípios, principalmente dos direitos fundamentais.

Tanto princípios quanto regras, como concebidos pela linha continental, trazem projeções sobre os seus destinatários. As regras projetariam condutas específicas a serem cumpridas, o que torna a projeção algo óbvio. Nos princípios, descritos como metas, a projeção apareceria difusa; contudo, se tomarmos teorias como a de Alexy, que colocam tais metas como mandados de otimização, isto é, como fins a serem alcançados, as condutas já se fariam presentes de modo embrionário. Isto porque os meios existem para os fins; definidos os fins, os meios são consequências. Se tomada a perspectiva de Alexy, onde toda norma espelharia um arcabouço positivo de fins, princípios e regras nada mais seriam que

\footnotetext{
${ }^{51}$ STRECK, Lenio Luiz. ABBOUD, Georges. O que é isto - o sistema (sic) de precedentes no CPC? in: Consultor jurídico. 18 de agosto de 2016. Disponível em: http://www.conjur.com.br/2016-ago-18/ensoincomum-isto-sistma-sic-precedentes-cpc. Acesso em 19.08.2016.
} 
Revista Eletrônica de Direito Processual - REDP.

Rio de Janeiro. Ano 11. Volume 18. Número 2. Maio a Agosto de 2017

Periódico Quadrimestral da Pós-Graduação Stricto Sensu em Direito Processual da UERJ

Patrono: José Carlos Barbosa Moreira. ISSN 1982-7636. pp. 393-436

www.redp.uerj.br

graduações da mesma estrutura ${ }^{52}$ - daí a atenção em formular conteúdos essenciais pelo exercício negativo à promoção do princípio $^{53}$. Otimização, termo usado por esta doutrina, revela-se incrementação dos fins, reunidos numa multiplicidade abstratamente desconexa, para sua consecução pelo e no litígio atual. Mantém-se a concepção contrafática, aumentando e diminuindo o foco da projeção. Mas esta é, antes, uma entre várias teorizações, não uma descrição da decisão ${ }^{54}$.

O erro de Alexy foi tentar dar um suporte positivo aos princípios (encontrar os princípios na própria lei). Dando-lhes contorno apriorístico em relação à ponderação, Alexy dá início à uma nova espécie de norma, distinta da noção de princípio tradicional (como princípios norteadores) e escondendo, conscientemente ou não, a possibilidade de ponderação da simples norma (a regra). Isso faz de Alexy exigir que se coteje a urgência do litígio, e não o evento ele mesmo, à constelação já positivada de princípios (seja essa constelação dada pela Constituição, seja pelos precedentes dos Tribunais Superiores). Por suplantar o substrato fático - desinteressado num comportamento específico, a preocupação torna-se eminentemente jurídico-normativa (validade) - naquele cotejamento é submetido antes a verificação dos próprios princípios. Ainda se manteria o método analítico, substituindo-se, tão somente, os objetos da aplicação. Não estão mais presentes ato e previsão normativa, mas o resultado da ponderação e o princípio. A consequência disto, como antes exposto, só pode ser a distorção da ponderação, bem como, agora, a preocupação maior com a revisão da própria normatividade.

Por outro lado, se lermos Levando os direitos a sério de cabo a rabo, perceberemos uma distância da concepção contrafática. Depois das seções sobre os modelos de regras, que formam os dois primeiros capítulos da sua obra, Dworkin dedica o restante do livro a

\footnotetext{
52 Mesma conclusão, mas numa análise não teleológica POSCHER, Ralf. Teoria de um fantasma: a malsucedida busca da teoria dos princípios pelo seu objeto; in: (Org) CAMPOS, Ricardo. Crítica da Ponderação: método constitucional entre a dogmática juríudica e a teoria social. São Paulo: Saraiva, 2016, p. 89.

${ }^{53}$ Propõe-se imaginar obstáculos à eficácia dos princípios para definição de um âmbito de proteção, assim firmado in SILVA, Virgílio Afonso da. Direitos fundamentais: conteúdo essencial, restrições e eficácia. São Paulo: Malheiros, 2009, p. 71.

${ }^{54}$ MASTRODI, Josué. Ponderação de direitos e proporcionalidade das decisões judiciais; in Revista Direito GV 20. São Paulo, Jul-dez de 2014, p. 584. Disponível em: http://www.scielo.br/pdf/rdgv/v10n2/18082432-rdgv-10-2-0577.pdf . Acesso em 16.03.2017.
} 
Revista Eletrônica de Direito Processual - REDP.

Rio de Janeiro. Ano 11. Volume 18. Número 2. Maio a Agosto de 2017

Periódico Quadrimestral da Pós-Graduação Stricto Sensu em Direito Processual da UERJ

Patrono: José Carlos Barbosa Moreira. ISSN 1982-7636. pp. 393-436

www.redp.uerj.br

aprofundar sua concepção de princípio. Lá ele faz referências aos conflitos sociais e problemas políticos concretos, principalmente a dos movimentos dos direitos civis nos Estados Unidos, para firmar, por exemplo, a defesa da igualdade e da dignidade ${ }^{55}$. E isso não acontece de um modo utilitarista. Entram em cena grandezas da dignidade do evento, como qualidades morais ${ }^{56}$. Fala-se de justiça, de bondade, de retidão. As metas de Dworkin não se colocam como fins, mas como virtudes e excelências. Para deixar claro: excelências não são valores (eclipsando a noção de trunfos). Não se pergunta, diante desta espécie de normas, se as ações são "boas para" o princípio. Nada aqui é passível de otimização. Toda axiologia é superada. Não há projeções. Excelências são questões éticas; busca-se "porquês".

O grande problema desta estrutura normativa está no fato de que justiça, bondade, retidão não podem ser linguisticamente apreendidas. Tratam-se de termos imprecisos, abertos a conotações voláteis e controversas. Embora consigamos reconhecer publicamente um evento como justo ou injusto, todo conceito de justiça é sempre insatisfatório ${ }^{57}$. Ao que parece, toda excelência é vazia de substância. Elas nunca existem por si - e por isso não podem ser delimitadas semanticamente ${ }^{58}$. Ao litígio recai o encargo de tornar justiça e injustiça um fenômeno perceptível e a condição básica dessa manifestação é o seu ajuizamento (institucional ou não). Carente de uma conduta ou uma postura específica em sua proposição, com estas normas é impossível uma aplicação no sentido tradicional. Como grandeza, excelências escapam do fenômeno normativo, restando para a norma, nesta estrutura, manifestar somente aspirações e repudiar exaltações - fazendo que a definição negativa de conteúdos essências converta-se em instrumento de identificação de preconceitos ${ }^{59}$. Por isso não se questiona mais qual conduta os sujeitos deveriam ter tomado, mas sim qual o sentido das ações em jogo.

\footnotetext{
${ }^{55}$ DWORKIN, Ronald. Taking Rights Seriously. Cambridge: Harvard, 1978, p. 248.

${ }^{56}$ Ibid., p. 250.

${ }^{57}$ RIBAS, Christina Miranda. Justiça em tempos sombrios: A justiça no pensamento de Hannah Arendt. Ponta Grossa: UEPG. 2005, p. 104-107.

${ }^{58}$ Toda beleza seria perdida se julgada por conceitos, como diria KANT, Immanuel. Crítica da faculdade do juízo. Trad. pt. de Valerio Rohdeh e António Marques, 2. ed. Rio de Janeiro: Forense Universitária, 2005, p. 60 [25].

${ }^{59}$ A questão não se encerra aí. Por se estruturar através de uma excelência, julgando antes o sentido do ato, e não o ato em si, os direitos fundamentais não conhecem de sanção (nem como toda norma objeto de ponderação). De um lado, seu descumprimento se dá por ignorância, pois presume, como em Platão, que
} 
Revista Eletrônica de Direito Processual - REDP.

Rio de Janeiro. Ano 11. Volume 18. Número 2. Maio a Agosto de 2017

Periódico Quadrimestral da Pós-Graduação Stricto Sensu em Direito Processual da UERJ

Patrono: José Carlos Barbosa Moreira. ISSN 1982-7636. pp. 393-436

www.redp.uerj.br

E, pela estrutura dos princípios (bem como toda norma objeto de ponderação), observa-se uma estranha limitação quanto a sua eficácia. Por servir de justificação ao ato, a eficácia desta espécie de norma está condicionada à prestação jurisdicional. Não só isto. Por mais que motive a ação, a ação não está intrinsecamente agarrada à vontade que lhe deu causa, tomando rumos bem diversos ao que foi querido. Isso faz que o papel do princípio não seja a outra face da causa de pedir ${ }^{60}$, opondo-se aos fatos, mas um instrumento de prestação de contas do julgador. Embora possa existir decisões que sejam tomadas como consequência de uma construção normativa, depurando de dispositivo a dispositivo legal uma conclusão (numa leitura exegética do inc. I e II do $\$ 1^{\circ}$ do art. 489 do Código de Processo Civil), cotidianamente depara-se primeiro com a tomada de posição do julgador e depois a procura de argumentos normativos que a corrobore ${ }^{61}$.

É possível que se conceba a conclusão e se construa um argumento para sustentálo - isso quando, por comodidade, o julgador não se esconde atrás de argumentos jurídicos prontos ou projeta sua vontade através das normas. Não é verdadeiro que o julgador não possa deduzir, graças à e somente pela verossimilhança, a decisão a partir do cotejamento entre fato e norma. Mas passa a ser falso, nesta lógica, que há uma construção interpretativa da decisão - regras de interpretação e de aplicação, destituídas de peso de fundamento ${ }^{62}$, e

ninguém faria o mal conscientemente. O próprio autor da infração passa a ser vítima, merecendo, então, uma espécie de segunda chance. A lógica aí é a da expiação, a salvação da alma, a exemplo da ressocialização do condenado penal e da justiça restaurativa no processo civil. A incidência da norma acontece sobre o modo de pensar das pessoas. Basta lembrarmos do caso Ellwanger. De outro lado, essa responsabilidade, ainda que abafada, dispensa a caracterização de dano, possibilitando então a tutela inibitória: impede-se a violação dos direitos fundamentais antes mesmos de ela acontecer, como na recente proibição da publicação Mein Kampf no Brasil. Cf. RIBAS DE LIMA, Manoel Pedro. Antinomos: da modulação da estrutura da norma frente aos relacionamentos intersubjetivos. Curitiba: Juruá, 2016, p. 111.

${ }^{60}$ Não havendo a correspondência contrafática da norma, isto é, dispensando a exigência do apontamento de aplicação analítica da norma, a pretensão (como condição ao conhecimento da ação judicial - C.Civil, art. 189, c/c CPC, art. 17) não exige a causa de pedir próxima (como fundamento jurídico prévio). Sendo isto correto, explica-se a retirada da possibilidade jurídica como condição da ação.

${ }^{61}$ GÉNY, François. Méthode d'interprétation et sources em droit privé positif. 2. Ed. 1919, v. 2. P. 316, n. 216, nota 3, apud. RODRIGUES, Silvio. Dos vícios do consentimento. 3. Ed. São Paulo: Saraiva, 1989, p. 51 e FERRAZ JUNIOR, Tércio Sampaio. A ciência do direito. $2^{\text {a }}$ Ed. São Paulo: Atlas, 1986, p. 92.

${ }^{62}$ ROSS, Alf. Direito e Justiça. Trad. Edson Bini. Bauru: Edipro, 2003, p. 102. A interpretação, por si, não é passível de determinação que lhe seja a priori, sob pena das regras de interpretação se sobreporem à interpretação ela mesma. Neste mesmo sentido Habermans critica o que chamou de modelo economicista de fundamentação de Alexy. Em HABERMAS, Jüngen. Direito e democracia: entre validade e facticidade. Trad. Flávio Beno Siebeneichler. V. I. 2 ed. Rio de Janeiro: Tempo Brasileiro, 2003, p. 321. 
Revista Eletrônica de Direito Processual - REDP.

Rio de Janeiro. Ano 11. Volume 18. Número 2. Maio a Agosto de 2017

Periódico Quadrimestral da Pós-Graduação Stricto Sensu em Direito Processual da UERJ

Patrono: José Carlos Barbosa Moreira. ISSN 1982-7636. pp. 393-436

www.redp.uerj.br

normas jurídicas materiais, que reclamam por um peso que não possuem, são incapazes de determinar imediatamente a decisão. Constrói-se interpretativamente tão somente a fundamentação da decisão. A decisão, por sua vez, pode remeter, e ordinariamente remete, para um momento e faculdade além das normas (ou de suas possíveis interpretações). Uma vez tomada a decisão, aí sim, constrói-se a fundamentação.

Não se prova, no sentido de demonstração efetiva, uma decisão; a fundamentação relata antes como se chegou às razões expostas. Por isso, não são princípios ou regras, normas em gerais e demais construções linguísticas a priori, que fazem uma decisão boa; eles devem antes ser apenas fatores negativos (controlando a decisão frente a uma formação normativa ${ }^{63}$ ). A comunicabilidade que torne possível ao público criticá-la, positiva e negativamente, passa a ser a grande chave. Espera-se das outras pessoas a mesma capacidade de julgar - afinal, uma opinião só vale quando compartilhada. Só a publicidade e a discussão pública das razões da decisão superarão o firmamento particularizado do julgamento.

\section{O RESULTADO DA CONVIVÊNCIA ENTRE OS EFEITOS DOS PRECEDENTES E A PONDERAÇÃO}

Como exposto pelo trabalho, são contraditórios efeitos verticais dos precedentes, assim como delineado pelo Código de Processo Civil, e o exame de ponderação. Cada postulado alimenta pressupostos e pretensões antagônicas. Pelos precedentes presume-se um sistema mecânico normativo fechado e a identidade entre casos diferentes, buscando assim maior objetividade em nome da segurança jurídica. $\mathrm{O}$ exame de ponderação inclina-se à justiça e à imparcialidade mediante a abertura e circunscrição do discurso normativo (ao ponto de positivamente o superar) e à singularidade do caso. Se houve uma preocupação com a segurança jurídica na sua conotação tradicional (a objetividade na resolução de litígios), não faz sentido acumular ponderação e precedentes no mesmo código.

Os precedentes não são uma reação histórica à ponderação, tampouco o sentido oposto. Parece haver antes apropriações precipitadas de tradições alienígenas. A ponderação

\footnotetext{
${ }^{63}$ WEBER, Max. O direito na economia e na sociedade. São Paulo: Ícone, 2011, p. 83
} 
Revista Eletrônica de Direito Processual - REDP.

Rio de Janeiro. Ano 11. Volume 18. Número 2. Maio a Agosto de 2017

Periódico Quadrimestral da Pós-Graduação Stricto Sensu em Direito Processual da UERJ

Patrono: José Carlos Barbosa Moreira. ISSN 1982-7636. pp. 393-436

www.redp.uerj.br

veio, ao que tudo indica, para a correção metodológica. Já a noção dos precedentes, devidamente distorcida, parece atender uma necessidade pragmática do Poder Judiciário em facilitar tanto a consonância institucional entre diferentes tribunais quanto no gerenciamento das decisões. A contradição apresentada coloca-se como paradoxo político. Se há uma exigência institucional de uma integração normativa em vista de um progresso jurídico geral (que, apesar de seu espectro liberal, é altamente legítimo porque, a exemplo da Igreja, possibilitaria um influxo temporal da própria instituição), depara-se também com a demanda pela dignidade do litígio atual e de seus litigantes. Na perspectiva tanto do jurisdicionado quanto das instâncias ordinárias, a ponderação é formalmente democrática, pois conta com a participação ativa de todos os atores jurídicos. Na perspectiva dos tribunais superiores, a eficácia dos precedentes assegura uma integridade institucional de todo o Poder Judiciário mediante a investidura daqueles tribunais como autoridade (augere $)^{64}$. Isto pode ser dito quando depara-se com o resultado da convivência entre precedentes e ponderação da forma encontrada no Código de Processo Civil.

Como dito antes, os precedentes sistematizam hermeticamente a atuação das instâncias ordinárias, exigindo destas uma atuação mecânica. Juízes monocráticos e tribunais de justiças veem-se obrigados tão somente a aplicar acriticamente as decisões dos tribunais superiores $^{65}$. Já os tribunais superiores encontram, por sua competência, caminho aberto à ponderação. Ao receberem os recursos oriundos das instâncias ordinárias, os tribunais superiores não podem rever o relatório das circunstâncias fáticas (exame probatório), mas deve sim recebê-los como casos concretos. Preocupados com a revisão da validade das normas (o controle de constitucionalidade e o judicial review em geral - CPC, art. 928, parágrafo único), eles não apenas podem mudar de opinião (CPC, art. $927, \S \S 3^{\circ}$ e $\left.4^{\circ}\right)^{66}$, mas também têm em mãos o caso concreto passível de ponderação. E a ponderação é, por si e por seus objetos, impossível de sistematização. O sistema é aberto por cima.

\footnotetext{
${ }^{64}$ Neste sentido STRECK, Lenio Luiz. Por que commonlistas brasileiros querem proibir juízes de interpretar? in: Consultor jurídico. 22 de setembro de 2016. Disponível em: http://www.conjur.com.br/2016set-22/senso-incomum-commonlista-brasileiros - juízes-interpretar?. Acesso em 23.09.2016.

${ }^{65}$ Sob o aspecto material, indiretamente depara-se com a mitigação do direito de ação, pois se torna paliativo promover debates sobre teses já estabelecidas (CPC, art. 985).

${ }^{66} \mathrm{O}$ overruling, também previsto na Lei 11.471/2006, art. $3^{\circ}$.
} 
Revista Eletrônica de Direito Processual - REDP.

Rio de Janeiro. Ano 11. Volume 18. Número 2. Maio a Agosto de 2017

Periódico Quadrimestral da Pós-Graduação Stricto Sensu em Direito Processual da UERJ

Patrono: José Carlos Barbosa Moreira. ISSN 1982-7636. pp. 393-436

www.redp.uerj.br

A abertura pelo alto faz com que não seja possível encontrar um sentido intrínseco e perene ao ordenamento. Os tribunais superiores jamais figuram como fonte de produção normativa, já que se reclama, ainda que inconsideradamente, a preexistência positiva dos princípios. Aliás, por força do princípio da legalidade, a norma legal sempre se colocará acima do precedente. Essa janela atua como uma espécie de funil. São selecionados argumentos jurídicos que mais lhes aprouver dentre a infinidade de possibilidades. No entanto, pelo fissuramento, desagrega-se todos os precedentes. Exemplo é a reviravolta no conceito de capitalização ocorrido com o Recurso Especial n ${ }^{\circ}$ 973.827/RS (o que antes era concebido como juros compostos - uma forma específica de aplicação - passou a ser tido como a incidência de juros remuneratórios sobre os juros remuneratórios inadimplidos, sem prejuízo aos juros moratórios - a cumulação de aplicações). O intérprete terá uma novela sem sentido à qual, dinamicamente, frustra toda expectativa de segurança jurídica. Todo precedente far-se-á sempre transição, mas o desenvolvimento nunca será progressivo ${ }^{67}$.

A grande crise será conciliar ambos os postulados no ato de julgamento. Ao mesmo tempo que caberá às instâncias ordinárias a atenção estrita ao que é dito como correto pelos tribunais superiores também devem elas buscar a correção do caso pelos seus próprios termos. Apesar do segundo postulado estar aberto ao diálogo com o primeiro, este não é recíproco. Justifica-se, a partir disso, a pressuposição de invalidade da decisão de primeira instância, ou porque deixou de replicar o precedente, ou porque deixou de lado a ponderação; o que, pragmaticamente, motiva ainda mais a pretensão recursal e o acúmulo de processos nos tribunais (tanto nos tribunais de justiça, a quem cabe o exame de admissibilidade, quanto aos tribunais superiores, na recepção de agravos de instrumentos contra decisão que denegue a admissibilidade - CPC, art. 1.030 e 1.042).

A distinção entre funções para as instâncias ordinárias e para as instâncias extraordinárias, proposta por Mitidiero como solução da problemática relação entre eficácia vertical dos precedentes e a ponderação, tem efeito paliativo para o ato do julgamento.

\footnotetext{
${ }^{67}$ Embora essa abertura pareça garantir uma maior autonomia ao Poder Judiciário, parece ser ela, antes, um sintoma do desgaste da noção de soberania do Estado, fragmentando o ordenamento jurídico em diversos âmbitos institucionais distintos. Ver RIBAS DE LIMA, Manoel Pedro. Antinomos: da modulação da estrutura da norma frente aos relacionamentos intersubjetivos. Curitiba: Juruá, 2016, cap. II.
} 
Revista Eletrônica de Direito Processual - REDP.

Rio de Janeiro. Ano 11. Volume 18. Número 2. Maio a Agosto de 2017

Periódico Quadrimestral da Pós-Graduação Stricto Sensu em Direito Processual da UERJ

Patrono: José Carlos Barbosa Moreira. ISSN 1982-7636. pp. 393-436

www.redp.uerj.br

Segundo ele, as cortes de justiça têm um papel de "exploração dos possíveis significados dos textos jurídicos a partir do controle da justiça do caso concreto", o que é passível de dispersão dos sentidos dos julgamentos diante as inúmeras possibilidades de decisão, enquanto as cortes superiores teriam casos concretos apenas como meios para se chegar a uma uniformização do Direito ${ }^{68}$. Embora tal diferença possa repercutir pragmaticamente na carga de trabalho dos tribunais superiores, ela não elimina, no julgamento do caso concreto seja na instância que for, a imperatividade dos precedentes e sua exigência por enquadramentos.

O destino previsível a curto prazo para a eficácia dos precedentes sobre os julgamentos, atada a uma postura positivista que ainda não se encerrou, não aceitará a conciliação com o seu conflitante. Sua oposição com o exame de ponderação não é, necessariamente, um dilema. Para sua resolução, inevitavelmente, exigirá uma ruptura na sua concepção legal - ou em direção da superação do método analítico, ou o seu recondicionamento para fora da normatividade ${ }^{69}$.

5. CONCLUSÃO: distinção entre tese jurídica e decisão

Os leitores que persistiram até aqui puderam perceber a dissonância das exposições e hipóteses deste trabalho diante da doutrina publicada nos últimos anos. As razões são simples: nosso começo não foi a importação de pensamentos outros mas a teorização da prática cotidiana. Também não se conta, ainda, com uma ruptura histórico-institucional, mas uma continuidade em outros moldes. Porém não se pode esquivar das contradições conceituais. Todas elas gravitam na noção de racio decidendi. Inicialmente, conceber a tese jurídica como enquadrando típico, aplicado analiticamente, conflita com a formulação

${ }^{68}$ MITIDIERO, Daniel. Precedentes: da persuasão à vinculação. 2 ed. São Paulo: Revista dos Tribunais, 2017, p. 78.

${ }^{69}$ Como alternativa da hipótese ora descrita é o exercício de sopesamento do enquadramento típico que define a tese jurídica proposta legalmente no julgamento do litígio atual. Não se nega nem o geral, nem o particular. O precedente vale enquanto projeção abstrata, e, por isso, com eficácia generalizada. Pelo precedente reclamase estabilidade, uma vez que por ele se exige honras mesmo sem assegurar grau algum de previsibilidade da decisão. Ela nunca iluminará o caso concreto satisfatoriamente. O caso, por sua vez, demanda particularidade, sob pena de violação de sua dignidade e da de seus litigantes. 
Revista Eletrônica de Direito Processual - REDP.

Rio de Janeiro. Ano 11. Volume 18. Número 2. Maio a Agosto de 2017

Periódico Quadrimestral da Pós-Graduação Stricto Sensu em Direito Processual da UERJ

Patrono: José Carlos Barbosa Moreira. ISSN 1982-7636. pp. 393-436

www.redp.uerj.br

acadêmica. Em seguida, o papel da norma na ponderação também não se comunica com a concepção de parte dos processualistas, principalmente dos defensores da eficácia vertical dos precedentes.

Apropriada do common law, a ratio decidendi corresponde aos motivos que levaram a tomada de posição do julgador em determinado sentido. Destes motivos extrai-se, pela prática do common law, proposição que ganham força normativa pelo desenvolvimento institucional do Poder Judiciário (binding). Embora essa apreensão da proposição aconteça com o ressalto de um precedente (holding), a proposição em si é uma abstração ${ }^{70}$. É o que foi exposto anteriormente: essa proposição transcende o julgamento do caso concreto.

Esta exposição nos leva a crer que (i) ou fundamentos da decisão e ratio decidendi se divorciam ao longo do tempo, ou que (ii) ratio decidendi, entendida como fundamento, divorcia-se da normatividade encontrada na decisão (binding). Se entendida a primeira possibilidade, então a ratio decidendi é a proposição normativa extraída do precedente (flertando ela, não obstante sua estrutura e a dimensão material de sua eficácia, à nossa tese jurídica), mas não a decisão em si. Segundo Goodhart, a fundamentação não se faz imprescindível para o reconhecimento do precedente (uma vez que até de argumentos ruins é possível extrair boas regras ${ }^{71} \mathrm{e}$, complementa-se, diferentes argumentos podem sustentar a mesma decisão). Disto, Mello e Barroso chegam ao ponto de proporem aos tribunais superiores formularem enunciados ao concluírem cada julgamento ${ }^{72}$. Já se nos determos na segunda alternativa, a ratio decidendi não corresponde à unidade do Direito, mas à comunicabilidade da decisão. Isto porque os motivos do julgamento superam a norma preexiste. Servindo como instrumentos de prestação de contas de decisões futuras, a ratio decidendi não poderia ser sumarizada em um enunciado e sua vinculação ao litígio atual dependeria muito do contexto ao qual fosse cotejada (como um diamante, cada precedente

\footnotetext{
${ }^{70}$ CARDOZO, Benjamin N. A natureza do processo judicial: palestras proferidas na Universidade de Yale. Trad. pt. Silvana Vieira e Alvaro de Vita. São Paulo: Martins Fontes, 2004, p. 16

${ }^{71}$ GOODHART, Arthur L. Determining the racio decidendi of a case; in The Yale Law Journal. Vol. 40. N. 2. Dez. 1930, p. 165. Disponível em: http://www.umiacs.umd.edu/ horty/courses/readings/goodhart-1930ratio.pdf. Acesso em 02/03/2017.

${ }^{72}$ BARROSO, Luís Roberto. MELLO, Patrícia Perrone Campos. Trabalhando com uma nova lógica: a ascensão dos precedentes no direito brasileiro, p. 3-4. Out/16. Disponível em http://www.conjur.com.br/2016out-28/artigo-barroso-explica-precedentes-cpc-muda-direito. Acesso em 31/01/2017. O que nos parece um erro, já que a ratio decidendi é extraída, antes, pelo leitor do que dado pelo redator.
} 
Revista Eletrônica de Direito Processual - REDP.

Rio de Janeiro. Ano 11. Volume 18. Número 2. Maio a Agosto de 2017

Periódico Quadrimestral da Pós-Graduação Stricto Sensu em Direito Processual da UERJ

Patrono: José Carlos Barbosa Moreira. ISSN 1982-7636. pp. 393-436

www.redp.uerj.br

teria várias facetas). Seu papel seria meramente exemplificativo e, caso ganhe algum caráter normativo, isso aconteceria graças à uma identidade atribuída pela sua sucessiva aplicação.

Fato é que, com esse caráter transcendente da ratio decidendi (como concebida pela common law), a doutrina brasileira reprovará a concepção da eficácia material dos precedentes como enquadramentos típicos. Arroga essa doutrina ter sido apropriado pelo Código de Processo Civil vigente uma eficácia material amplificada, aplicada pela seleção de aspectos comuns entre os casos (relevantes semelhanças ou identidade essencial), não obstante o contexto legal e institucional encontrado hoje no Brasil. Para que essa eficácia dilatada fosse recepcionada no cotidiano jurisdicional brasileiro, seria necessário, no mínimo, (i) dissociar a tese jurídica à uma imperatividade imediata, (ii) revogar a particularização das decisões dos tribunais, como recursos repetitivos e súmulas, e (iii) superar a exigência de contextualização fática para a alteridade. Mas, sem a expedições de enquadramentos típicos, não seriam os tribunais superiores responsáveis pela formação dessa jurisprudência consolidada, senão restaria uma consolidação gradativa defendida ativa e reiteradamente pelos julgados, pela doutrina e pelos próprios cidadãos - o assentimento geral a um juízo comum, sempre futura ao próprio precedente, que daria sua eficácia normativa $^{73}$. Diferentemente do que acredita Streck e Abboud ${ }^{74}$, essa alteração não depende apenas de uma postura, mas de alteração legal, já que o enquadramento típico tem raízes no Código de Processo Civil.

A segunda colocação deste trabalho, servindo-lhe de conclusão, é a denúncia de uma confusão nefasta entre os neoconstitucionalistas e processualistas atuais. Para eles, valendo-se da distinção entre texto e norma, proclama-se a atividade judicial como reconstrução do sentido das proposições legais. Encontramos em Marinoni e Mitidiero o ápice dessa posição: norma seria o resultado da decisão judicial, onde o sentido do enunciado

\footnotetext{
${ }^{73}$ EDDEY, Keith. The English Legal System. 3. Ed. Londres: Sweet \& Maxwell, 1982, p. 125 apud ABBOUD, Georges. Súmula vinculante versus precedentes: notas para evitar alguns enganos; in: WAMBIER, Teresa Arruda Alvim (Coord.). Revista de Processo. Nov/2008. Ano 33. n. 165. São Paulo: Revista dos tribunais, 2008, p. 219. Mantidas as condições atuais, cada decisão de recurso repetitivo seria, para os litígios contemporâneos ao que lhe funda, uma imposição retroativa (CPC, art. 525, §14, e art. 985, I).

${ }^{74}$ STRECK, Lenio Luiz; Abboud, Geroges. O solilóquio epistêmico do ministro Roberto Barroso sobre precedentes in: Consultor jurídico. 03 de novembro de 2016. Disponível em http://www.conjur.com.br/2016nov-03/senso-incomum-soliloquio-epistemico-ministro-barroso-precedentes. Acesso em 04.11/2016.
} 
Revista Eletrônica de Direito Processual - REDP.

Rio de Janeiro. Ano 11. Volume 18. Número 2. Maio a Agosto de 2017

Periódico Quadrimestral da Pós-Graduação Stricto Sensu em Direito Processual da UERJ

Patrono: José Carlos Barbosa Moreira. ISSN 1982-7636. pp. 393-436

www.redp.uerj.br

concretizar-se-ia no julgamento do caso particular. Essa colocação entende como discurso jurídico a concreção da indeterminação textual para normatizar o litígio e delinear as consequências ${ }^{75}$. Numa distorção do realismo jurídico (para quem a juridicidade da norma se confirma no tribunal, mas não que a norma não aplicada não seja norma ${ }^{76}$ ), este pensamento entende que a normatividade da proposição só se manifestaria em sede jurisdicional.

Não se pode negar que toda sentença é potencialmente constitutiva (no sentido de Carnelutti). Mas posição como a de Marinoni e de Mitidiero é, de um lado, confundir os instrumentos com a própria obra e, de outro lado, é negar a normatividade no cotidiano (alheio da atividade jurisdicional).

Como a alegoria de Hart, deixar ao Judiciário a confirmação do Direito é como tornar possível mudar a regra do jogo após a jogada já ter acontecido ${ }^{77}$. Disto duas conclusões lógicas surgem. A primeira está no fato de que, ao dar a última palavra sobre o caso concreto, o Judiciário confirma tão-somente sua autoridade na resolução do litígio. A segunda é que, ao tomar uma posição diferente da norma jurídico positiva pré-existente, a decisão ou recai em ilegalidade ou, a exemplo da ponderação, ab-roga a norma (o que não significa, necessariamente, uma violação do ordenamento, senão que a norma em questão não é incidente ao caso). Decisão e norma são, na perspectiva do litígio atual, duas coisas distintas. A norma, anterior a decisão, possui uma carga significativa própria. A decisão, embora se faça norma às partes, é, perante a norma pré-existente, um fenômeno novo e com sentido extraordinário.

É correto dizer que o Estado Democrático, e não apenas Constitucional, não pode entender a norma como projeto do legislador (mens legislatoris). Por outro lado, norma não está restrita à decisão. Pessoas convivem dia-a-dia umas com as outras, praticando atos e fechando negócios que, em sua maioria, jamais chegam aos gabinetes dos magistrados. A

\footnotetext{
${ }^{75}$ MITIDIERO, Daniel. Fundamentação e precedente: dois discursos a partir da decisão judicial; in Revista de Processo, V. 37. São Paulo: Revista dos Tribunais, 2012, p. 68.

${ }^{76} \mathrm{O}$ realismo ainda distingue o meramente normativo, a exemplo da moral, do jurídico, que seria a norma reconhecida institucionalmente. Ver ROSS, Alf. Direito e Justiça. Trad. Edson Bini. Bauru: Edipro, 2003, p. 85.

${ }^{77}$ HART. H. L. A. The concept of law. Oxford: Oxford University Press, 1961, p. 59, 67, 139. De outro modo, confundir-se-á vigência normativa (existência) com validade (neste contexto, adequação à aplicação).
} 
Revista Eletrônica de Direito Processual - REDP.

Rio de Janeiro. Ano 11. Volume 18. Número 2. Maio a Agosto de 2017

Periódico Quadrimestral da Pós-Graduação Stricto Sensu em Direito Processual da UERJ

Patrono: José Carlos Barbosa Moreira. ISSN 1982-7636. pp. 393-436

www.redp.uerj.br

norma é o entendimento compartilhado entre os seus destinatários: os cidadãos. Se norma fosse o produto da decisão jurisdicional, a grande maioria das relações cotidianas jamais poderão ser qualificadas como jurídicas. E a decisão como a única manifestação da norma no caso, sempre a posteriori ao próprio litígio, autorizaria ao juiz não apenas ab-rogar a norma positivada (um critério de validade ao caso), mas ignorar ostensivamente a estrutura institucional de uma comunidade (colocando-se acima da vigência do ordenamento). Acreditar que norma só se concretiza com a decisão judicial é criar um solipsismo institucional e político ${ }^{78}$.

Não se discorda do fato de que o entendimento do texto legal ou jurisprudencial, sempre abstrato e portanto equívoco, nunca satisfaz o caso concreto. Todavia, dizer que norma é o resultado da decisão jurisdicional representa a absurda distorção da denotação do termo "interpretação". Retira-se o produto interpretativo que é a norma (o conteúdo significativo do enunciado - um construído sempre dependente intrinsecamente de um dado anterior) para transpô-la para um momento compreensivo (uma tomada de posição encontrando algo além do que está dado). É como ver chifre em cabeça de cavalo. Há uma ilógica tentativa de salvar o discurso normativo delatando, ironicamente, sua limitação.

Se confundido decisão ("aplicação" da norma) com a norma ela mesmo, estrangular-se-á, por exemplo, o obiter dictum. Isto porque, como atesta o exame de ponderação, a norma jurídico positiva (legal ou jurisprudencial) utilizada no caso é apenas um dos recursos à mão do julgador. $\mathrm{O}$ motivo eficiente de sua decisão pode residir em outro fator (como na razoabilidade frente as peculiaridades do caso concreto). Quando um novo julgamento refere-se ao caso anterior, a ratio decidendi do caso anterior pode se portar normativamente, mas a norma "aplicada" no caso anterior pode não estar presente. Aquela norma será, então, secundária, obiter dictum para o novo julgamento.

Parece que o dilema aristotélico entre lei, entendida aqui como discurso normativo (seja qual for a origem do enunciado), e a equidade, como o julgamento do caso particular, jamais será resolvido. Normatividade e justiça são reclamações diferentes sobre a decisão.

\footnotetext{
${ }^{78}$ Se toda norma depende-se, para usa configuração, da manifestação judicial, como ficaria o Direito Público em geral, aplicado cotidianamente pela Administração Pública? Assim opõe-se Bobbio à tese de John Austin. BOBBIO, Norberto. O positivismo jurídico: lições de filosofia do Direito. São Paulo: Ícone, 2006, p. 168.
} 
Revista Eletrônica de Direito Processual - REDP.

Rio de Janeiro. Ano 11. Volume 18. Número 2. Maio a Agosto de 2017

Periódico Quadrimestral da Pós-Graduação Stricto Sensu em Direito Processual da UERJ

Patrono: José Carlos Barbosa Moreira. ISSN 1982-7636. pp. 393-436

www.redp.uerj.br

Sobrepor um discurso sobre outro será perpetuar a maldição da lei (Gálatas, 2:21). É preciso entender que a "perfeição" da lei vige no seu âmbito próprio: a busca de estabilidade sempre hesitante perante a contingência (nunca uma certeza). Do mesmo modo a "perfeição" do julgamento do caso concreto: a resolução de singularidade do litígio. A ponte entre eles não parece estar na aplicação da norma jurídico positiva (seja legal ou jurisprudencial) no caso, mas no respeito à norma para o julgamento justo.

\section{REFERÊNCIAS BIBLIOGRÁFICAS:}

ABBOUD, Georges. Súmula vinculante versus precedentes: notas para evitar alguns enganos; in: WAMBIER, Teresa Arruda Alvim (Coord.). Revista de Processo. Nov/2008. Ano 33. n. 165. São Paulo: Revista dos tribunais, 2008

ALEXY, Robert. Teoría de los derechos fundamentales. Madrid: Centro de Estudios Políticos y Constitucionales, 2002

ARENDT, Hannah. Liçoes sobre a filosofia política de Kant. $2^{\text {a }}$ ed. Rio de Janeiro: Relume-Dumará, 1994.

ARISTÓTELES. Ética a Nicômaco. $3^{\text {a }}$ Ed. Brasília: Editora Universidade de Brasília, 2001. AUGSBERG, Ino. A desumanidade da razão na multiplicidade de suas vozes: a teoria da ponderação e a sua crítica como um programa jurídico-teórico; in: (Org) CAMPOS, Ricardo. Crítica da Ponderação: método constitucional entre a dogmática jurídica e a teoria social. São Paulo: Saraiva, 2016.

ÁVILA, Humberto. Teoria dos Princípios: da definição à aplicação dos princípios jurídicos. 11ª ed. São Paulo; Malheiros, 2010.

BARROSO, Luís Roberto. MELLO, Patrícia Perrone Campos. Trabalhando com uma nova lógica: a ascensão dos precedentes no direito brasileiro, p. 7. Out/16. Disponível em: http://www.conjur.com.br/2016-out-28/artigo-barroso-explica-precedentes-cpc-mudadireito.

BENJAMIN, Walter. A obra de arte na era de sua reprodutibilidade técnica, in Id. Magia e técnica, arte e política: ensaios sobre literatura e história da cultura. $8^{\mathrm{a}}$ Ed. São Paulo: Brasiliense, 2012. 
Revista Eletrônica de Direito Processual - REDP.

Rio de Janeiro. Ano 11. Volume 18. Número 2. Maio a Agosto de 2017

Periódico Quadrimestral da Pós-Graduação Stricto Sensu em Direito Processual da UERJ

Patrono: José Carlos Barbosa Moreira. ISSN 1982-7636. pp. 393-436

www.redp.uerj.br

BERGSON, Henri. A energia espiritual. São Paulo: Editora WMF Martins Fontes, 2009.

BOBBIO, Norberto. O positivismo jurídico: lições de filosofia do Direito. São Paulo: Ícone, 2006.

CARDOZO, Benjamin N. A natureza do processo judicial: palestras proferidas na Universidade de Yale. São Paulo: Martins Fontes, 2004.

DWORKIN, Ronald. Taking Rights Seriously. Cambridge, Harvard, 1978.

FERRAZ JUNIOR, Tércio Sampaio. A ciência do direito. $2^{\text {a }}$ Ed. São Paulo: Atlas, 1986.

FERRAZ JUNIOR, Tércio Sampaio. Introdução ao estudo do direito: técnica, decisão, dominação. 4. ed. São Paulo: Atlas, 2003, p. 193.

FOUCAULT, Michel. Vigiar e punir: nascimento da prisão. Trad. pr. Raquel Ramalhete. 42 $2^{\mathrm{a}}$ ed. Petrópolis: Vozes, 2014.

G1. Condenado pela morte do pai, Gil Rugai tem prisão decretada em SP. 22/02/2016.

Disponível em: http://g1.globo.com/sao-paulo/noticia/2016/02/condenado-pela-morte-dopai-gil-rugai-tem-prisao-decretada-em-sp.html.

GOODHART, Arthur L. Determining the racio decidendi of a case; in The Yale Law Journal. Vol. 40. N. 2. Dez. 1930, p. 169. Disponível em: http://www.umiacs.umd.edu/ horty/courses/readings/goodhart-1930-ratio.pdf.

HABERMAS, Jüngen. Direito e democracia: entre validade e facticidade. Trad. Flávio Beno Siebeneichler. V. I. 2 ed. Rio de Janeiro: Tempo Brasileiro, 2003.

HART. H. L. A. The concept of law. Oxford: Oxford University Press, 1961.

JASPERS, Karl. Origen y meta de la historia. $4^{\circ}$ ed. Madrid: Revista de Occidente, 1968. KANT, Immanuel. Crítica da faculdade do juízo. 2. ed. Rio de Janeiro: Forense Universitária, 2005.

KELSEN, Hans. Teoria pura do Direito. 6. ed. São Paulo: Martins Fontes, 1998.

MARINONI, Luiz Guilherme. Teoria geral do processo. Vol.1. $7^{\text {a }}$ ed. São Paulo: Revista dos Tribunais, 2013.

MASTRODI, Josué. Ponderação de direitos e proporcionalidade das decisões judiciais; in Revista Direito GV 20. São Paulo, Jul-dez de 2014, p. 584. Disponível em: http://www.scielo.br/pdf/rdgv/v10n2/1808-2432-rdgv-10-2-0577.pdf. 
Revista Eletrônica de Direito Processual - REDP.

Rio de Janeiro. Ano 11. Volume 18. Número 2. Maio a Agosto de 2017

Periódico Quadrimestral da Pós-Graduação Stricto Sensu em Direito Processual da UERJ

Patrono: José Carlos Barbosa Moreira. ISSN 1982-7636. pp. 393-436

www.redp.uerj.br

MITIDIERO, Daniel. Fundamentação e precedente: dois discursos a partir da decisão judicial; in Revista de Processo, V. 37. São Paulo: Revista dos Tribunais, 2012.

Precedentes: da persuasão à vinculação. 2 ed. São Paulo: Revista dos Tribunais, 2017.

NOGUEIRA, Gustavo Santana. Jurisprudência vinculante no direito norte-americano e no direito brasileiro; in WAMBIER, Teresa Arruda Alvim. (Coord.). Revista de Processo. Ano 33, nº 161. São Paulo: Revista dos Tribunais, jun/2008, p. 112.

POSCHER, Ralf. Teoria de um fantasma: a malsucedida busca da teoria dos princípios pelo seu objeto; in: (Org) CAMPOS, Ricardo. Crítica da Ponderação: método constitucional entre a dogmática juríudica e a teoria social. São Paulo: Saraiva, 2016.

PUGLIESE, William. Precedentes e a civil law brasileira: interpretação e aplicação do novo código de processo civil. São Paulo: Revista dos tribunais, 2016.

RIBAS DE LIMA, Manoel Pedro. Antinomos: da modulação da estrutura da norma frente aos relacionamentos intersubjetivos. Curitiba: Juruá, 2016.

; GOBBO, Isabela Sens Fadel. A instabilidade institucional do poder judiciário pelo conflito entre controle concentrado de constitucionalidade e controle difuso. In: XII Simpósio Nacional de Direito Constitucional, 2016, Curitiba. XII Simpósio Nacional de Direito Constitucional, 2016.

RIBAS, Christina Miranda. Justiça em tempos sombrios: A justiça no pensamento de Hannah Arendt. Ponta Grossa: Editora UEPG. 2005.

RODRIGUES, Silvio. Dos vícios do consentimento. 3. Ed. São Paulo: Saraiva, 1989

ROSS, Alf. Direito e Justiça. Bauru: Edipro, 2003.

SILVA, Virgílio Afonso da. Direitos fundamentais: conteúdo essencial, restrições e eficácia. São Paulo: Malheiros, 2009.

STRECK, Lenio Luiz. ABBOUD, Georges. O que é isto - o sistema (sic) de precedentes no CPC? in: Consultor jurídico. 18 de agosto de 2016

STRECK, Lenio Luiz. Por que commonlistas brasileiros querem proibir juízes de interpretar? in: Consultor jurídico. 22 de setembro de 2016. Disponível em: http://www.conjur.com.br/2016-set-22/senso-incomum-commonlista-brasileiros-juízesinterpretar?. 
Revista Eletrônica de Direito Processual - REDP.

Rio de Janeiro. Ano 11. Volume 18. Número 2. Maio a Agosto de 2017

Periódico Quadrimestral da Pós-Graduação Stricto Sensu em Direito Processual da UERJ

Patrono: José Carlos Barbosa Moreira. ISSN 1982-7636. pp. 393-436

www.redp.uerj.br

STRECK, Lenio Luiz; ABBOUD, Geroges. O solilóquio epistêmico do ministro Roberto

Barroso sobre precedentes in: Consultor jurídico. 03 de novembro de 2016. Disponível em

http://www.conjur.com.br/2016-nov-03/senso-incomum-soliloquio-epistemico-ministro-

barroso-precedentes.

WAMBIER, Teresa Arruda Alvim. Estabilidade e adaptabilidade como objetivos do direito: civil law e common law; in Revista de Processo. Vol. 172. Jun/2009, p. 121 (p.4 e 15)

WEBER, Max. O direito na economia e na sociedade. São Paulo: Ícone, 2011. 